\title{
Two letters from Otto Neugebauer to Thomas Eric Peet on ancient Egyptian mathematics ${ }^{\text {光 }}$
}

\author{
Christopher D. Hollings* \\ Mathematical Institute, Woodstock Road, Oxford, OX2 6GG, UK \\ The Queen's College, Oxford, OX1 $4 A W, U K$ \\ R. B. Parkinson \\ Faculty of Oriental Studies, Pusey Lane, Oxford, OX1 2LE, UK \\ The Queen's College, Oxford, OX1 $4 A W, U K$
}

\begin{abstract}
We describe two letters of 1926 from the historian of mathematics Otto Neugebauer to the Egyptologist Thomas Eric Peet (Griffith Institute Archive, Oxford: Peet MSS 4.9). The letters concern Neugebauer's study of certain parts of the Rhind Mathematical Papyrus, as found in the doctoral dissertation that he had completed in Göttingen that year, for which Peet's 1923 edition of the papyrus was a major source. In the letters, we see the young Neugebauer establishing himself within the wider Egyptological community. The letters open up a discussion of Peet's own work on ancient Egyptian mathematics.
\end{abstract}

\section{Zusammenfassung}

Wir beschreiben zwei Briefe des Mathematikhistorikers Otto Neugebauer an den Ägyptologen Thomas Eric Peet aus dem Jahr 1926 (Griffith Institute Archive, Oxford: Peet MSS 4.9). Diese Briefe handeln von Neugebauers Studien über bestimmte Passagen des mathematisches Papyrus Rhind, die er in seiner Doktorarbeit aus demselben Jahr vornahm. Neugebauer hatte nämlich

\footnotetext{
This paper is warmly dedicated to Meter M. Neumann, Emeritus Fellow of The Queen's College, Oxford, in thanks for inspiring and encouraging the present work.

*Corresponding author Email addresses: christopher.hollings@maths.ox.ac.uk (Christopher D. Hollings), richard.parkinson@orinst.ox.ac.uk (R. B. Parkinson)
} 
als Hauptquelle auf Peets Edition des Papyrus von 1923 zurückgegriffen. In diesen Briefen können wir beobachten, wie sich der junge Neugebauer im erweiterten Kreis der Ägyptologen etabliert. Die Briefe eröffnen zugleich eine Diskussion über Peets eigene Arbeiten zur altägyptischen Mathematik.

Keywords: Otto Neugebauer, Thomas Eric Peet, ancient Egyptian mathematics, Egyptian fractions, Rhind Mathematical Papyrus 2010 MSC: 01A60, 01A70, 01A16

\section{Introduction}

The name Otto Neugebauer (1899-1990) is very well known to historians of mathematics. Thanks to his extensive works on the history of ancient mathematics, spanning several decades of the twentieth century, he is an extremely prominent figure in the discipline. Indeed, despite the fact that some aspects of his approach are today considered outdated from a methodological point of view, ${ }_{1}^{1}$ Neugebauer arguably had a significant role to play in the early professionalisation of the history of mathematics during the twenty years prior to the Second World War (Rowe, 2012).

Thomas Eric Peet (1882-1934), on the other hand, is a figure who is rather less known to historians of mathematics, except perhaps to those who study ancient Egyptian mathematics. An archaeologist by training, Peet eventually moved in a more philological direction. One of his significant works was a transcription, translation, and commentary of the Rhind Mathematical Papyrus (hereafter, RMP) in the British Museum, a major source on ancient Egyptian mathematics. It is the RMP that links Peet with Neugebauer.

Peet's edition of the RMP appeared in 1923, around the time that the young Neugebauer was beginning his studies of ancient Egyptian mathematics (Peet, 1923a). Knowing of Neugebauer's interests, his Copenhagen-based colleague, the mathematician Harald Bohr (1887-1951), invited him to write a review of Peet's edition for the Danish mathematical journal Matematisk tidsskrift. This review, written in German, became Neugebauer's first published article (Neugebauer, 1925) and sparked the work that was to form the basis of his doctoral dissertation, Die Grundlagen der ägyptischen Bruchrechnung (Neugebauer, 1926).

\footnotetext{
${ }^{1}$ See, for example, the comments in Robson (2007, p. 60) or Imhausen (2009, p. 781).
} 
While pursuing his doctoral research, Neugebauer appears to have been in regular correspondence with Peet, and duly sent him a copy of the completed dissertation..$^{2}$ The two letters of our title have recently come to light within the pages of this copy, now held in a library in Oxford $!^{3}$

The letters both date from 1926, and bracket the completion of Neugebauer's dissertation, which was defended on 21st April that year: in the first, dated 12th April, Neugebauer provided Peet with a mathematically detailed preview of some of the content of his forthcoming work, while the second, of 22nd August, is a short note in which Neugebauer indicated that Peet should now have received a copy. Both letters feature a number of small remarks that reveal the young Neugebauer's attempts to integrate himself into the wider Egyptological community. Moreover, the earlier and longer letter provides us with an outline of Neugebauer's early thinking on the topic of ancient Egyptian fractions, an area in which his work was somewhat influential.

In this paper, we present transcriptions and translations of the two letters, and provide accompanying notes. We begin in the following four subsections with some background detail on the RMP, Neugebauer, Peet, and ancient Egyptian fractional arithmetic, respectively. The earlier and longer letter appears in Section 2, with the shorter one following in Section 3. The paper ends with some concluding remarks in Section 4, where we contrast the styles of Neugebauer and Peet, and open up a discussion of the latter's contributions to the early study of ancient Egyptian mathematics.

\subsection{The Rhind Mathematical Papyrus}

The Rhind Mathematical Papyrus was written $c .1537$ BCE in the Second Intermediate Period in regnal year 33 of King Apepi, though its introductory title claims that it is a copy of something $c .200$ years older, which places the content of the papyrus in the late Twelfth Dynasty. It is written in a neat cursive script ('hieratic'), allying it with the sphere of administrative and literary texts rather than monumental inscriptions in hieroglyphs. After the title, the text is written in horizontal lines in both black ink and red ink; ruled black guidelines were used to lay out the surface of the recto and

\footnotetext{
${ }^{2}$ The title page carries the inscription "Herrn Prof. T. E. Peet / übereicht [sic] vom Verfasser" ("To Prof. T. E. Peet / presented by the author").

${ }^{3}$ The letters have subsequently been moved to the archive of the Griffith Institute, Oxford University's Egyptology institute (http://archive.griffith.ox.ac.uk/index. $\mathrm{php} /$ ), and are catalogued there as Peet MSS 4.9.
} 
most of the verso to facilitate the arrangement of the text, as was common in administrative accounts and ledgers (see, for example, Parkinson 2005, p. xiv). The papyrus was apparently placed in a tomb, perhaps in the burial of its copyist, and possibly with other technical manuscripts (Peet 1923a, pp. 1-3; Imhausen 2003, p. 65). Such deposits of papyri were displays of the tomb-owner's social and cultural status (Parkinson, in press, pp. 140141). The RMP was purchased in Thebes (modern Luxor) in 1858 by the Scottish lawyer and excavator Alexander Henry Rhind (1833-1863). 4 After Rhind's death, it was acquired by the British Museum in 1864, and was first mentioned in print as a 'Traité de Géométrie' by the archaeologist François Lenormant in 1867 (Lenormant 1867; Michel 2014, p. 21). Its first curator at the British Museum, Samuel Birch, similarly focused only upon the geometrical problems in the papyrus in his brief account of it (Birch, 1868). As is often the case with purchased artefacts and papyri, no records had been kept of its findspot, although it was later (and unreliably) "said to have been found at Thebes in a chamber in the ruins of one of the small buildings near the Ramesseum" in the necropolis on the west bank (Budge, 1898, p. 1). It was registered at the British Museum as two large fragments, P. BM EA 10057 and P. BM EA 10058, $5^{5}$ having been broken into two sections by whoever uncovered it; smaller surviving fragments were acquired by the New York Historical Society (Peet, 1923a, pp. 1-2) and are now held by the Brooklyn Museum 6

The papyrus is a compendium of more than 80 mathematical problems ${ }^{7}$ grouped by theme, representing a range of problems and solutions that might be encountered during a scribal career. Modern readers have divided up the papyrus into the following broad parts (with further subdivisions, beyond those listed here — see, for example, Peet 1923a, pp. 4-5):

\footnotetext{
${ }^{4}$ On Rhind, see Bierbrier $(2012$, p. 463) and Irving and Maitland (2015).

5 https://www.britishmuseum.org/collection/object/Y_EA10057; https://www . britishmuseum.org/collection/object/Y_EA10058 (last accessed 29th April 2020).

${ }^{0}$ https://www.brooklynmuseum.org/opencollection/objects/118304 (last accessed 27th April 2020).

${ }^{7}$ The original labelling of the text in the mid-nineteenth century identified 87 problems, although 85-87 were recognised as later additions. Problems 7B, 59B, 61B, and 82B have been added to the count by subsequent modern readers. For a detailed discussion of the layout of the papyrus and the grouping of the problems, see Spalinger (1990). Diagrams showing the structure of the papyrus may be found in Griffith (1891/1894, Pl. I), Peet (1923a, p. 3), and Chace (1927/1929, vol. II, preceding the section of photographs).
} 


$$
\begin{aligned}
& \text { [Recto]: } \\
& \quad \text { - title; } \\
& \quad-2 \div n \text { table (see Section } 1.4) \\
& \quad \text { - arithmetic (Problems } 1-40) \\
& \quad \text { - (blank stretch of papyrus); } \\
& \quad \text { - geometry/mensuration (Problems 41-60). }
\end{aligned}
$$

[Verso]:

- miscellaneous arithmetical problems (Problems 61-84);

- later additions and jottings on the remaining space (Problems 8587).

Much of our knowledge of how ancient Egyptian scribes handled the topics listed above (the arithmetic of fractions in particular) derives from the RMP.

Early comments on the papyrus were made by Birch (1868) and Griffith (1891/1894). In 1877, the German Egyptologist August Eisenlohr (18321902) had produced an initial facsimile of the RMP with accompanying treatise, which was considered by the 1920 s to be "both antiquated and unsatisfactory in treatment" with wrong readings and an "abstruse" analysis of the mathematics (Gunn 1926, p. 123; see Imhausen 2003, p. 8). In 1898, the British Museum had published a facsimile version without any commentary (Budge, 1898), muddling the arrangement of the text so that "one might think that a blind man had been entrusted with the division of the British Museum plates" (Gunn, 1926, p. 123, n. 1). Peet's edition (Peet, 1923a), which we discuss elsewhere in this article, was followed a few years later by that of Chace (1927/1929) (on which, see Section 2.3.3). A modern publication, with colour photographs of the whole, is that of Robins and Shute (1987). Although it lacks the title of the papyrus and Problems 7-20, Imhausen (2003) contains what is essentially a new edition of the rest of the text. Nowadays, the focus in the literature is usually on the details of individual problems from the papyrus, rather than on the text as a whole; see, for example, Bertato (2018).

\subsection{Otto Neugebauer (1899-1990)}

Since we believe that our readership will be more familiar with Neugebauer's biography than Peet's, we keep our account of the life of the former 
brief, but in Section 1.3 we offer a slightly fuller biographical sketch of the latter 8

Neugebauer studied mathematics and physics in Graz and Munich after the First World War, and then moved in 1922 to Göttingen, where he studied mathematics with Richard Courant (1888-1972), Edmund Landau (1877-1938), and Emmy Noether (1882-1935). It was also in Göttingen that his interest in ancient Egyptian mathematics was sparked, and he was able to study there with the successive professors of Egyptology, Hermann Kees (1886-1964) and the great philologist Kurt Sethe (1869-1934) ${ }^{9}$

As already noted, Neugebauer's earliest publication was a glowing review of Peet's edition of the RMP, which served to spark his further interest in the way in which certain parts of the content of the papyrus had been constructed. A detailed account of his findings formed his dissertation, which was followed by a philological note (Neugebauer, 1927) and two papers on ancient Egyptian arithmetic (Neugebauer, 1929, 1930), plus one on geometry (Neugebauer, 1931).

By the early 1930s, however, the bulk of Neugebauer's work on ancient Egyptian mathematics was behind him, and he had turned instead to the study of ancient Mesopotamian mathematics and astronomy, a subject on which he would publish extensively throughout the rest of his life, alongside material on Egyptian astronomy. As in the case of Egyptian mathematics, Neugebauer learnt the languages necessary for the study of the ancient Mesopotamian material, and often worked in collaboration with specialists at his institutions.

With the rise to power of the Nazis in 1933, life became difficult for Neugebauer in Göttingen owing to his liberal views and his defence of persecuted Jewish colleagues, and so in 1934 he accepted an invitation from Harald Bohr to take up a professorship in Copenhagen, another university with a strong Egyptology department, founded in 1924. Neugebauer remained in Copenhagen until the end of the decade, whereupon he accepted a professor-

\footnotetext{
${ }^{8}$ For more detailed biographies of Neugebauer, see Bierbrier (2012, pp. 401-402), Davis (1994), Pingree (1990), and Swerdlow (1993), as well as the volume Jones et al. (2016). For (incomplete) bibliographies of Neugebauer's work, see Anon (1962) and Sachs and Toomer (1979).

${ }^{9}$ On whom, see Bierbrier (2012, pp. 290-291, 502-503). Sethe was professor from 1907 until his move to Berlin in 1923, whereupon he was succeeded by Kees, who held the chair until his dismissal as a Nazi sympathiser in 1945.
} 
ship at Brown University in the USA (a third university with an important Egyptology department), a post that he held until his retirement in 1969.

Despite modern concerns about Neugebauer's approach to the history of mathematics (see above), there is no denying his influence on the field. In line with German Egyptological traditions, his focus was on texts: the compilation of source collections for ancient mathematics and astronomy was a major theme of Neugebauer's work ${ }^{10}$ He was also a co-founder (together with Julius Stenzel and Otto Toeplitz) of the Springer series 'Quellen und Studien zur Geschichte der Mathematik, Astronomie und Physik'. Neugebauer also played an active role within the mathematical community at large: for example, as Courant's assistant in the foundation of the Göttingen Mathematical Institute, and also as founding editor of two reviewing journals: Zentralblatt für Mathematik und ihre Grenzgebiete (in 1931), and Mathematical Reviews (1940). Perhaps owing to his own mathematical background, he was well known and respected in the European and North American mathematical communities; indeed, it might be said that it was his presence and stature that led mathematicians to take the history of mathematics seriously as a discipline.

\subsection{Thomas Eric Peet (1882-1934)}

Peet studied at The Queen's College, Oxford (1901-1905) 11 being elected to the Jodrell scholarship in Mathematics, and read for honours in "Classical and mathematical Moderations" (Gardiner, 1934a, p. 67). After his final exams he became interested in Mediterranean archaeology, and worked on Maltese and Italian sites (1906-1909). Being of "slender resources" (Gardiner, 1934a, p. 69), paid employment was essential, and he excavated in Abydos for the Egypt Exploration Fund 1909-1913. He met the Egyptologist Alan H. Gardiner (1879-1963) in Egypt in autumn 1909, and in 1911 learnt Egyptian with Gardiner in Oxford, becoming increasingly interested in "his philological studies" (Gardiner, 1934a, p. 69). Gardiner was an influential scholar of independent means, with strong links to German Egyptology; he influenced most appointments to academic posts in British Egyptology at

\footnotetext{
${ }^{10}$ For example, Neugebauer (1935-1937, 1955) and Neugebauer and Sachs (1945) on Babylonian texts, and Neugebauer and Parker (1960-1969) on Egyptian.

${ }^{11}$ For biographies of Peet, see Bierbrier (2012, pp. 420-21), Gardiner (1934a), and Gunn and Simpson (2004).
} 
this time 12 Peet became lecturer in Egyptology in the University of Manchester 1913-1928 (significantly, Gardiner was Reader in Egyptology there in 1912-1914: Simpson 2004a). After the war, he became Brunner Professor of Egyptology at Liverpool (1920-1933), the previous holder, Percy Newberry (1868-1949), having resigned in his favour (Gardiner, 1934a, p. 70). From 1921, he was editor of the Journal of Egyptian Archaeology, and was Laycock Student in Egyptology at Worcester College, Oxford in 1923.

In 1917, he published a study of the hieroglyphic inscriptions in Sinai with Gardiner, and in 1920 he published the hieratic Mayer Papyri in Liverpool (Gardiner and Peet 1917; Peet 1920). By the 1910s, with advances in the understanding of Middle Egyptian, a new edition of the hieratic text of the RMP was felt to be "badly needed" (Gunn, 1926, p. 123), and Peet undertook a new edition and study; this was published in 1923 by the Liverpool University Press. In the preface, Peet stated that he had begun work on the RMP in 1911, but laid it aside in 1914, and had resumed work on it after the war in 1920 (Peet, 1923a, Preface). Given that 1911 was when he studied with Gardiner, it is tempting to speculate that Gardiner had steered him towards it because of his earlier training in mathematics; Gardiner later noted that he had taught Peet only Late Egyptian in 1911, as he already had "a good working knowledge of Middle Egyptian" (Gardiner, 1934a, p. 68). Peet thanked Gardiner in his edition of the RMP for "as usual ... many an admirable suggestion". Indeed, some of the correspondence between Peet and Gardiner held in the archive of the Griffith Institute in Oxford ${ }^{13}$ points towards Gardiner's having read the unpublished manuscript, and also having used it (1920-1921) as a source of reference during the compilation of his Egyptian grammar (Gardiner, 1927); conversely, the same correspondence hints at Peet's own input (c.1925) into the Grammar - particularly the mathematical parts. Peet's edition of the RMP was his first publication dealing specifically with Egyptian mathematics, and was followed by several articles (Peet 1923b, 1931a; Gunn and Peet 1929), reviews (Peet, 1930a b c), and a published lecture series (Peet, 1931b).

Peet became Reader and Fellow of The Queen's College, Oxford in 1933, and was "Professor-Elect" of Egyptology (Gardiner, 1934b). He gave his inaugural lecture as Reader at the University on 17th January 1934 (Peet

\footnotetext{
${ }^{12}$ On Gardiner, see Bierbrier (2012 pp. 205-207) and Simpson (2004a).

${ }^{13}$ AHG/42.230 T.E.Peet LETTERS.
} 
1934b; Lewis 2016, pp. 7-8), and had already "won golden opinions" (Gardiner, 1934a, p. 66), but be died on 22nd February, "shortly before the readership had been definitely converted into a chair" (Gunn and Simpson, 2004). Following his death, his personal library, including his copy of Neugebauer's dissertation, was purchased from his executors by Gardiner and donated to The Queen's College as the 'Peet Memorial Library' 14 These books joined those bequeathed by the recently-deceased professor of Assyriology, Archibald Henry Sayce (1845-1933), and they were initially housed in Sayce's former college rooms ('The Sayce room(s)') which were taken over by Peet's immediate successor, Battiscombe Gunn (see Section 2.3.1). After several changes in location (Baines, 2013), the 'Peet Library' is now housed in the new Queen's College library. ${ }^{15}$ and it is here that the documents of our title were discovered by the first author in June 2018, within the pages of Peet's copy of Neugebauer's dissertation (shelfmark: QA22 .NE). The shorter letter that appears in our Section 3 was pasted along one edge onto the initial blank page of the dissertation, while the longer letter (Section 2) was tucked loosely in the same place.

Peet was regarded as an exceptionally rounded scholar with a "breadth of interests" (Gardiner, 1934a, p. 66), and an approach to ancient Egypt that tried to avoid imposing modern ideas on the subject matter ${ }^{16}$ This is notable in his comparative study of Egyptian literature, where he urged scholars to approach it in a manner that would allow it to "take its proper place among the literatures of the world" (Peet, 1934b, p. 16). In his inaugural lecture he commented in a similar vein:

No side of Egyptian mental activity has been more discussed or written about in the last fifteen years than mathematics. Writers are insisting more and more on the necessity of tearing ourselves away from all modern conceptions and trying to start with blank minds, if we are to understand the process by which the Egyptians reached their results ... We are coming to see that what is true of mathematics must also be true of all activities of the mind ...

\footnotetext{
${ }^{14}$ The Queen's College Record 2(2) (1934), 9.

15 https : //www.queens.ox.ac.uk/peet-library

${ }^{16}$ Clare Lewis has used the term 'anti-presentist' to describe this approach: see, for example, https://podcasts.ox.ac.uk/endowment-enterprise-and-emendationhistory-egyptology-queens (accessed 27th April 2020).
} 
(Peet, 1934b, pp. 19-20)

This characteristic approach is stated clearly in the Preface to his edition of the RMP: "Egyptian mathematics was a simple affair, and the author has tried throughout to deal with it in its own simple terms without clothing it in a modern dress which is totally foreign to it" (Peet, 1923a, Preface).

\subsection{Ancient Egyptian fractions}

Although only a very small number of original sources has survived for us to study, we have a reasonably clear picture of how ancient Egyptian arithmetic worked 17 The RMP, as discussed in Section 1.1, is one of the most complete and extensive sources on ancient Egyptian mathematics, and is probably the most thoroughly studied of the extant mathematical papyri. The RMP is central to the work of Neugebauer and Peet that we will survey here.

As is well documented in both academic and popular writings on the history of mathematics, the scribes of ancient Egypt employed a decimal numerical notation without position, together with a system of fractions composed almost entirely of (in modern terms) unit fractions ${ }^{18}$ Calculations with both integers and fractions were performed in a two-column arrangement, as illustrated by the simple (hypothetical) example shown in Figure 1. drawn from Peet (1923a, p. 13). In the example, we seek to multiply 15 by 13 , so we begin by writing down ' 1 ' and ' 15 ' at the top of what will be two columns (Ritter 2000 refers to this as the 'initialisation' of the problem). We then repeatedly double both numbers, entering the values into the relevant columns. The goal is to obtain numbers in the first column that will add together to make our other factor, 13. Having doubled our numbers three times, we see that the 1 , the 4 and the 8 in the first column add to 13 , and so the corresponding numbers in the second column, 15, 60 and 120, add to give the required answer of 195 . The rows in which we are interested are marked with a slash ('Y'), which is the manner in which ancient Egyptian scribes indicated the relevant rows (though not always consistently). We could also

\footnotetext{
${ }^{17}$ For an index of extant sources concerning ancient Egyptian mathematics, see Imhausen (2016. p. 233). We take Imhausen (2016) as our main general reference; on fractions specifically, see Imhausen $(2016, \S 10.3)$.

${ }^{18}$ For the forms of Egyptian numerals, both hieroglyphic and hieratic, see Imhausen (2016. Tables 1 and 3) and Gillings (1972, Appendix 12).
} 


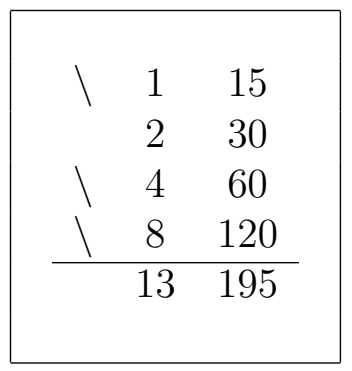

Figure 1: Simple example of ancient Egyptian arithmetic: $15 \times 13$.

have begun the problem by writing down 1 and 13 as our initialisation, and then seeking numbers in the first column that add to 15. This two-column method was the standard technique for performing multiplication in ancient Egypt, though doubling was not the only operation that was permitted, as we shall see shortly. Division is also possible in a broadly similar way: in this instance, we would take 1 and the divisor as our initialisation, and seek the dividend as a total of entries in the second column, before reading off the corresponding entries in the first, which add to give the quotient.

Within ancient Egyptian arithmetic, most fractions, being unit fractions, were denoted by the corresponding integer in combination with a dot to indicate that the number was a fraction 19 A small number of fractions had their own distinct signs, namely $\frac{1}{2}, \frac{1}{3}, \frac{1}{4}$, and $\frac{2}{3}$, the latter enjoying a special status as the only non-unit fraction that was regularly employed in calculations. For the most part, Egyptian scribes seem to have viewed their fractions as $n$th parts of integers - hence the focus on unit fractions. Where a division resulted in an answer that was not a unit fraction, it was therefore necessary to express this as a sum of unit fractions: for example, the result of dividing 2 by 5 would be expressed as $\frac{1}{3}+\frac{1}{15}$. The problem of how Egyptian scribes divided 2 by an odd integer (alternatively, doubled an odd unit fraction) and expressed the result as a sum of unit fractions is one that was central to Neugebauer's early work, as we shall see. In what follows, we will employ a notation for Egyptian fractions that was in fact introduced by Neugebauer in his dissertation: instead of $\frac{1}{n}$, we write $\bar{n}$. The

\footnotetext{
${ }^{19}$ The integer-plus-dot notation is that of hieratic texts, but it has its counterpart in hieroglyphic numerals, where the integer appears below the sign $r \propto$ (Gardiner Sign List D21).
} 
special fraction $\frac{2}{3}$ is written $\overline{\overline{3}}$. Juxtaposition is used to denote addition of fractions: the example given above may be rewritten as $2 \div 5=\overline{3} \overline{15}$.

Based on the evidence of extant sources, the full range of permissible operations within the two-column scheme has been outlined by Ritter (2000):20

- doubling;

- halving;

- multiplying by 10 ;

- dividing by 10 ;

- taking $\frac{2}{3}$ of a number;

- 'inversion': if the numbers in one row read ' 4 7', for example, then we may write down a new row ' $\overline{7} \quad \overline{4}$ '.

One further technique that was only gradually understood by modern scholars is that of the so-called red auxiliaries, named for the colour of ink used by Egyptian scribes to write down certain numbers within a problem. ${ }^{21}$ An understanding of the red auxiliaries is key to the interpretation of Neugebauer's dissertation, and of the remarks that he sent to Peet. We illustrate this method by considering Problem 23 from the RMP ${ }^{22}$ which appears in Figure 2; those numbers that appear in the papyrus in red ink are shown here in bold 23

The problem is to 'complete' $\overline{4} \overline{8} \overline{10} \overline{30} \overline{45}$ to $\overline{\overline{3}}$, that is, to subtract the former from the latter. The numbers that appear in bold beneath the first

${ }^{20}$ We note further that both Ritter $(2000)$ and Imhausen $(2002,2003)$ have emphasised the algorithmic nature of ancient Egyptian mathematics in its deployment of these operations.

${ }^{21}$ On the method of red auxiliaries, see Gillings (1972, Chapter 8) and Imhausen (2016. $\S 10.2 .2)$. Red ink was used to emphasise and differentiate text, much like modern italics, including, for example, the opening words of the title of the RMP and the headings of problems; this usage for auxiliaries is a specialised mathematical version of this practice (see, for example, Posener 1951).

${ }^{22}$ Our presentation of RMP Problem 23 is a synthesis of those given by Peet $1923 \mathrm{a}$, p. 59) and Gillings (1972, p. 85).

23 Peet (1923a) used underlining to indicate red ink in his transcriptions, and italics in his transliterations, while Neugebauer (1926) (and Imhausen 2016) used bold, as here. 


$$
\begin{array}{cccccc}
\overline{4} & \overline{8} & \overline{10} & \overline{30} & \overline{45} & \text { Complete into } \overline{\overline{3}} \\
\mathbf{1 1} & \mathbf{5} & \mathbf{4} & \mathbf{1} & \mathbf{1} & \\
\overline{\mathbf{4}} & \overline{\mathbf{2}} & \overline{\mathbf{2}} & \overline{\mathbf{2}} & & \\
& \overline{\mathbf{8}} & & & &
\end{array}
$$

Therefore $\overline{9} \overline{40}$ is what must be added to it, making $\overline{\overline{3}}$

$$
\begin{array}{ccccccccc}
\overline{4} & \overline{8} & \overline{9} & \overline{10} & \overline{30} & \overline{40} & \overline{45} & \overline{3} & \text { making } 1 \\
\mathbf{1 1} & \mathbf{5} \overline{\mathbf{2}} & \mathbf{5} & \mathbf{4} & \mathbf{1} \overline{\mathbf{2}} & \mathbf{1} \overline{\mathbf{8}} & \mathbf{1} & \mathbf{1 5} & \\
\overline{\mathbf{4}} & \overline{\mathbf{8}} & & \overline{\mathbf{2}} & & & & &
\end{array}
$$

Figure 2: Problem 23 from the RMP, illustrating the use of red auxiliaries; bold type indicates red ink in the original.

sum of fractions are the so-called 'red auxiliaries', which are derived via the use of a 'reference number'. Notice first of all that beneath the $\overline{45}$ in the first row, we have a bold 1 , namely the result of multiplying $\overline{45}$ by 45 . Next to this, and reading downwards, we have $1 \overline{2}$ beneath the $\overline{30}$ : the result of multiplying $\overline{30}$ by 45 . The pattern continues as we move to the left: each of the numbers in the first row is multiplied by 45 , and the result is written in a column underneath. We term 45 the reference number for the calculation. If we add up the bold numbers, we find that the total is $23 \overline{2} \overline{4} \overline{8}$, a rather easier number to work with that those with which we started. If we note further that $\overline{3} \times 45=30$, and that $30-23 \overline{2} \overline{4} \overline{8}=6 \overline{8}$, then all we have to do is divide $6 \overline{8}$ by 45 in order to obtain the desired result. Although the scribe has not provided us with the working ${ }^{24}$ this is a calculation that can be performed by using the two-column method for division that was described briefly above - that the scribe had indeed done this is suggested by the fact that such a two-column method is employed in similar problems elsewhere in the RMP: for example in the adjacent Problem 22 (Peet, 1923a, p. 59). The quotient of $6 \overline{8}$ by 45 is indeed the $\overline{9} \overline{40}$ that is given in the problem, which concludes, as do many other problems in the RMP, with a verification of the answer: the original $\overline{4} \overline{8} \overline{10} \overline{30} \overline{45}$ is combined with the $\overline{9} \overline{40}$ that has been found, together with an additional $\overline{3}$, so that the total ought to be 1 .

\footnotetext{
${ }^{24}$ The calculations $\overline{30} \times 45=1 \overline{2}$, etc. are similarly omitted.
} 
Once again 45 is taken as a reference number and each of the fractions is multiplied by 45 in turn to give the bold numbers written vertically at the bottom of the problem. These are easily added, and are found to total 45, thereby verifying the above answer.

We see then that the technique of using a reference number and red auxiliaries is reminiscent of the modern notion of choosing a least common multiple of a set of numbers 25 — but instead of arriving at a collection of integers, the Egyptian scribe would be content with a set of numbers that included 'nice' fractions such as $\overline{3}$ or so-called dimidiated fractions: those of the form $\overline{2^{n}}$. It seems reasonable to speculate that over time a scribe would develop an intuition regarding the choice of suitable reference numbers.

One final aspect of ancient Egyptian fractions that ought to be dealt with here is the issue of duplicating unit fractions that was alluded to above. From evidence within the RMP and elsewhere, it is clear that it was a known principle among scribes that if a fraction of the form $\overline{2 n}$ was to be doubled, then the answer was simply $\bar{n}$. Fractions of the form $\overline{2 n+1}$, however, were more problematic, and additional work was required to express the result of doubling such a fraction as a sum of unit fractions: we have already seen the example $\overline{3} \overline{15}$ as the result of doubling $\overline{5}$. In fact, this appears to have been a problem that was encountered so frequently that tables of standard expressions for the duplication of odd fractions were drawn up as works of reference ${ }^{26}$ The first part of the RMP, immediately after the title, is taken up by a copy of such a table: ${ }^{27}$ it gives expressions for the duplication of $\bar{n}$ for all odd $n$ between 3 and 101 . For example: twice $\overline{7}$ is $\overline{4} \overline{28}$, twice $\overline{9}$ is $\overline{6} \overline{18}$, and so on; in general, of course, such expressions will have more than two summands. The representation of $2 \div n$ as a sum of unit fractions is in general not unique, and much of the scholarship on ancient Egyptian mathematics has sought to explain why scribes chose the representations that they did, with consequent (occasionally acrimonious) debate ${ }^{28}$ Uniform

\footnotetext{
${ }^{25}$ Peet referred to this throughout his edition of the RMP as the "common denominator method" (Peet, 1923a, pp. 17-19).

${ }^{26}$ We note, however, that in the RMP this operation is consistently phrased as a division, rather than a duplication: njs 2 hnt ... ("divide 2 by ...": see Imhausen 2016, p. 93). Peet (1923a, p. 16) was confident that both interpretations were familiar to the scribe.

${ }^{27}$ Similar tables also appear in the Lahun Mathematical Fragments (see Imhausen and Ritter 2004 pp. 92-93, and Imhausen 2016, §10.3.1) and in the Mathematical Leather Roll (see Glanville 1927 and Imhausen $2016, \S 10.3 .2$ ).

${ }^{28}$ Alongside Neugebauer's, one of the early contributions to this discussion was that of
} 
methods of determining the representations have been sought, but without any universally accepted conclusions. ${ }^{29}$ As Imhausen (2007, p. 19) has put it:

There have been several attempts to explain the choices of representations in the $2 \div N$ table. These attempts were mostly based on modern mathematical formulas, and none of them gives a convincing explication of the values we find in the table. It is probable that the table was constructed based on experiences in handling fractions.

Since Neugebauer's dissertation represents an early contribution to this debate, we will return to this issue in Section 2.3.6.

\section{Letter of 12th April 1926}

This letter (Figures 3 6) is written on two folded sheets of cream writing paper with dimensions $31.4 \times 19.4 \mathrm{~cm}$. The creases show that these were folded down to $15.7 \times 9.7 \mathrm{~cm}$, presumably to fit inside an envelope (which is not preserved). The paper features a watermark with "MK PAPIER" in a circle and underneath "PUCK" (this type of writing paper was named after the entrepreneur Max Krause, 1838-1913). We note that the handwriting of the letters is in Latin script, rather than the German (Sütterlin) script that might have been expected of a German author of this period. In the absence of suitable comparanda, we are unable to say whether this was Neugebauer's usual script or whether he might even have adopted it specifically for his correspondence with Peet 30

Vogel (1929). Some of the most detailed arguments for particular methods have come from Gillings (1972, 1974, 1978, 1979), but with (rather polemical) criticism by Bruckheimer and Salomon (1977) and by Bruins in both Mathematical Reviews (MR0497458, MR0549821) and Zentralblatt für Mathematik und ihre Grenzgebiete (Zbl 0389.01001). Contributions to the debate over the construction of the $2 \div n$ table in the RMP are still being made: see, for example, Abdulaziz (2008).

${ }^{29}$ The fact that different texts feature the same representations of fractions has led to the belief by some scholars that there must have been a common set of principles behind their choice: see, for example, Gillings's 'precepts' (Gillings, 1972, p. 49).

${ }^{30}$ Handwritten corrections, seemingly Neugebauer's own, to a copy of his dissertation that survives in Princeton (see footnote 43 below) were made in Latin script, which may suggest that Neugebauer generally employed the latter, at least in a technical context. 



Figure 3: Letter of 12th April 1926, pp.1-2.
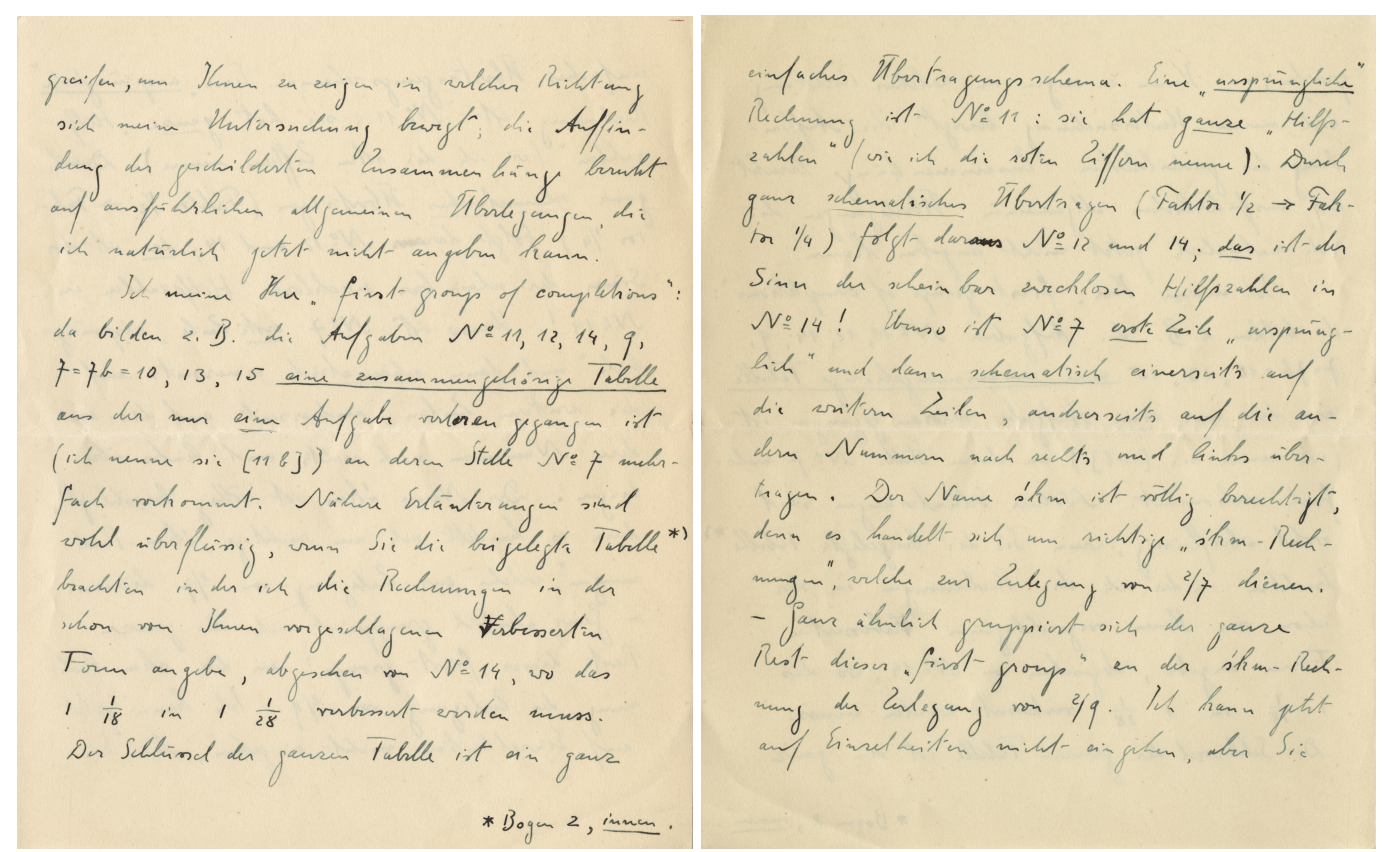

Figure 4: Letter of 12th April 1926, pp.3-4. 


\subsection{Transcription}

Göttingen, 12.4.26.

Gaussstr. 831

\section{Sehr geehrter Herr Professor!}

Besten Dank für Ihren freundlichen Brief, der mich sehr interessiert hat. Die Arbeit von B. Gunn zu lesen bin ich sehr begierig; alles[,] was ich bisher aus seiner Feder gelesen habe[,] hat mir sehr gut gefallen.

Bei dieser Gelegenheit erlaube ich mir gleich eine Anfrage: es ist schon lange mein Wunsch das „Journal of Egyptian Archaeology“ zu erhalten und ich wäre Ihnen daher sehr dankbar, wenn Sie mir mitteilen könnten, unter welchen Bedingungen und zu welchem Preise ein Bezug möglich wäre. Wenn es meine Mittel irgend erlauben, werde ich dann um $\mathrm{Zu}[2]$ sendung bitten.

Auch auf die Arbeiten von Prof. Archibald und $\mathrm{D}^{\mathrm{r}}$. Chace bin ich sehr neugierig. Es wird Sie vielleicht interessieren, wenn ich Ihnen auch ganz kurz von den Ergebnissen meiner eigenen Arbeit berichte, die, wenn nicht noch unvorhergesehene Hindernisse eintreten, in nächster Zeit unter dem Titel „Die Grundlagen der aeg. Bruchrechnung“ in den „Untersuchungen zur Gesch. u. Altertumskunde Aeg." von Prof. Sethe erscheinen wird. Ich möchte Sie aber ausdrücklich bitten, das Folgende als rein persönlich an Sie, Herr Professor, gerichtete Mitteilung auffassen zu wollen, und davon einstweilen noch keinerlei Gebrauch zu machen.

Ich will nur ein bestimmtes Beispiel heraus[3]greifen, um Ihnen zu zeigen in welcher Richtung sich meine Untersuchung bewegt; die Auffindung der geschilderten Zusammenhänge beruht auf ausführlichen allgemeinen Überlegungen, die ich natürlich jetzt nicht angeben kann.

Ich meine Ihre „first group of completions": da bilden z.B. die Aufgaben $\mathrm{N} \cong$ o $11,12,14,9,7=7 \mathrm{~b}=10,13,15$ eine zusammengehörige Tabelle[,] aus der nur eine Aufgabe verloren gegangen ist (ich nenne sie [11b]) an deren Stelle № 7 mehrfach vorkommt. Nähere Erläuterungen sind wohl überflüssig, wenn Sie die beigelegte Tabelle*) [at right-hand foot of page: *Bogen 2, innen.] beachten[,] in der ich die Rechnungen in der schon von Ihnen vorgeschlagenen verbesserten Form angebe, abgesehen von № 14, wo

\footnotetext{
${ }^{31}$ The address was added later in Peet's handwriting in darker ink, and presumably copied from the sender's address on the outside of the envelope for future reference.
} 



Figure 5: Letter of 12th April 1926, pp. 5, 8.

das $1 \frac{1}{18}$ in $1 \frac{1}{28}$ verbessert werden muss. Der Schlüssel der ganzen Tabelle ist ein ganz [4] einfaches Übertragungsschema. Eine „ursprüngliche“ Rechnung ist № 11: sie hat ganze „Hilfszahlen“ (wie ich die roten Ziffern nenne). Durch ganz schematisches Übertragen (Faktor 1/2 $\rightarrow$ Faktor 1/4) folgt daraus No 12 und 14; das ist der Sinn der scheinbar zwecklosen Hilfszahlen in № 14 ! Ebenso ist $\mathrm{N} \cong 7$ erste Zeile „ursprünglich“ und dann schematisch einerseits auf die weitern Zeilen, andererseits auf die anderen Nummern nach rechts und links übertragen. Der Name śkm ist völlig berechtigt, denn es handelt sich um richtige „śkm-Rechnungen“, welche zur Zerlegung von 2/7 dienen. - Ganz ähnlich gruppiert sich der ganze Rest dieser „first group“ zu der śkm-Rechnung der Zerlegung von 2/9. Ich kann jetzt auf Einzelheiten nicht eingehen, aber Sie [5] sehen wohl schon aus dem bisher Gesagten, dass sich nun ein ganz neuer Zugang zu den Zerlegungen $\frac{2}{2 n+1}$ ergibt: allerdings sehr abweichend von allen modernen Rekonstruktion [sic], sondern mit einem ziemlich aeg.-umständlichen Apparat, der aber völlig der aeg. „Multiplikations"-Methode nachgebildet ist. - Als Nebenresultat kommt noch heraus, dass man wh h in wzh tp $m$... immer durch „addieren" wiedergeben kann, denn die ganze Methode ist rein additiv. 


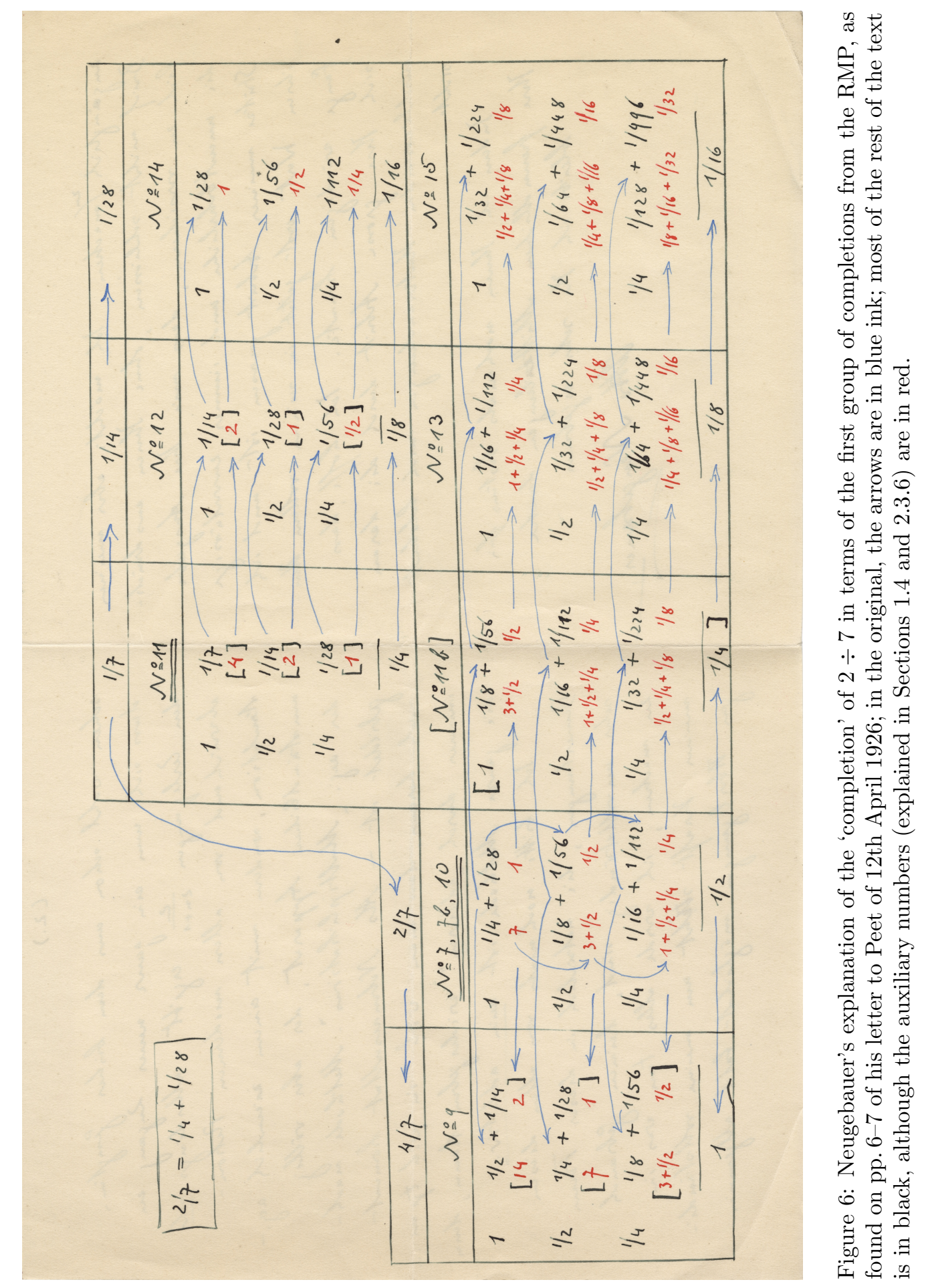


Ich bitte nochmals von allen diesen Bemerkungen, die natürlich in dieser Form sehr unvollständig sind, keinen Gebrauch zu machen; ich werde alles tun[,] was in meiner Kraft steht[,] um meine vollständigen Überlegungen möglichst bald allgemein [table here on double page 6-7: see our Figure 6] [8] zugänglich [zu inserted] machen. Ich möchte aber meinen Brief nicht schliessen, ohne Ihnen ausdrücklich zu versichern, dass mir Ihre Ausgabe die unentbehrliche und immer zuverlässige Stütze meiner Arbeit gewesen ist und ich ihren Wert erst jetzt in seinem vollem [sic] Umfange würdigen konnte. Ich hoffe, dass sich Ihre grosse Arbeit durch die daran anschliessenden Untersuchungen reich belohnt sieht.

Indem ich Ihnen nochmals bestens für Ihre freundlichen Mitteilungen danke

bleibe ich Ihr sehr ergebener

Otto Neugebauer

\subsection{Translation}

Göttingen, 12.4.26.

Gaussstr. 8

\section{Dear Professor,}

Many thanks for your friendly letter, which interested me very much. I am very eager to read the work by B. Gunn; everything that I have read from his pen so far I have liked very much.

On this occasion, I allow myself a request: it has long been my wish to receive the "Journal of Egyptian Archaeology" and I would therefore be very grateful if you could tell me under what conditions and at what prices a subscription would be possible. If my means permit, I will then ask for a [2] mailing.

I am also very curious about the works of Prof. Archibald and Dr. Chace. It might interest you if I also tell you very briefly about the results of my own work, which, if there are no unforeseen obstacles, will soon be published under the title "Die Grundlagen der aegyptischen Bruchrechnung" in Professor Sethe's "Untersuchungen zur Geschichte und Altertumskunde Aegyptens". But I would like to expressly ask you to interpret the following as a purely personal communication to you, Professor, and for the time being to make no use of it. 
I just want to single out a particular example [3] to show you in which direction my investigation is going; the discovery of the described connections is based on detailed general considerations, which of course I cannot specify now.

I mean your "first group of completions": there, for example, problem № $11,12,14,9,7=7 \mathrm{~b}=10,13,15$ form a related table from which only one problem has been lost (I call it [11b]), in its place № 7 appears several times. Further explanations are probably superfluous if you consider the enclosed table, $\left.{ }^{*}\right)$ [at right-hand foot of page: *Sheet 2, inside.] in which I indicate the calculation in the improved form already suggested by you, except for № 14 , where the $1 \frac{1}{18}$ in the $1 \frac{1}{28}$ has to be corrected. The key to the whole table is an entirely [4] simple transmission scheme. An "original" calculation is $\mathrm{N}$ 11: it has whole "auxiliary numbers" (as I call the red digits). By entirely schematic transmission (factor $1 / 2 \rightarrow$ factor $1 / 4$ ), № 12 and 14 follow; that is the meaning of the seemingly purposeless auxiliary numbers in $\mathrm{N} \equiv 14$ ! Similarly, № 7 is the first row "original" and then schematically transferred on the one hand on the further lines, on the other hand on the other numbers to right and left. The name śkm is completely justified, because it concerns real "śkm-calculations", which serve for the decomposition of 2/7. - Entirely similarly, the whole remainder of this "first group" is grouped into the skmcalculation of the decomposition of $2 / 9$. I cannot go into details now, but you [5] can see from what has been said that this results in a completely new approach to the decompositions $\frac{2}{2 n+1}$ : though very different from all modern reconstructions, but with a rather Egyptian-cumbersome apparatus, which nevertheless fully follows the Egyptian "multiplication" method. - As a side result, it turns out the $w_{3}$ h in $w_{3} h$ tp $m$... can always be reproduced by "adding", because the whole method is purely additive.

I ask again of all these remarks, which of course are very incomplete in this form, that no use be made; I will do everything in my power to make my full considerations generally accessible as soon as possible. [table here on double page 6-7: see our Figure 6] [8] But I do not want to close my letter without expressly assuring you that your edition has been the indispensable and always reliable support of my work and that I have only now been able to fully appreciate its value to the fullest extent. I hope that your great work will be richly rewarded by the resulting investigations.

Thanking you once again for your friendly communications

I remain your very devoted

Otto Neugebauer 


\subsection{Notes}

\subsubsection{B. Gunn}

Battiscombe Gunn (1883-1950) was a British Egyptologist, best known as a major philologist, "a most exacting critic [who] maintained an extraordinarily high standard" (Bierbrier, 2012, p. 232); Neugebauer's enthusiasm for his work was well-founded. Gunn had already provided Peet with "some valuable points" for the RMP edition (Peet, 1923a, Preface), and he published a substantial, highly detailed and largely philological review of it Gunn, 1926) ${ }^{32}$ he and Peet later collaborated on an article on the Moscow Mathematical Papyrus, another major source on ancient Egyptian mathematics (Gunn and Peet, 1929). He succeeded Peet both as Professor of Egyptology at Oxford and as editor of the Journal of Egyptian Archaeology (Bierbrier 2012, p. 232; Simpson 2004b).

The following letter (Section 3) records that this "work" of Gunn's arrived with Neugebauer in August 1926. It was almost certainly Gunn's review of Peet's edition of the RMP, which was published in the Journal of Egyptian Archaeology of 1926, and which Peet presumably had mentioned in his previous letter, perhaps as being currently in press. This hypothesis is consistent with what is known of the chronology of the publication: the Journal had initially been planned to be issued "quarterly each year in January, April, July and October" 33 but in 1917 because of the war, a decision was taken "to issue the second and third parts of Vol. IV of this Journal as a double number", according to an 'Editorial note', bound into the Peet Library's copy of the 1917 journal. The journal for 1926 contains two sets of 'Notes of recent publications' which are placed halfway through and at the end of the whole volume respectively; Gunn's review appeared in the first of these and so was probably printed around April. Peet certainly knew about the review before publication, not only because he was editor of the journal, but also because he was the one who had arranged for the Liverpool University Press to send a review copy of the book to Gunn in the first place 34 In the context of Neugebauer's letters, the "work" is unlikely to be the only other immediately relevant publication by Gunn, a review of Sethe's monograph

\footnotetext{
${ }^{32}$ Peet later noted of his edition of the RMP that it should be read in conjunction with Gunn's "invaluable review" (Peet, 1931b, p. 409, n. 2).

${ }^{33}$ 'Editorial Statement', Journal of Egyptian Archaeology 1 (1914), 1.

${ }^{34}$ This is reflected in a letter to Gardiner of 10th October 1924 (AHG/42.230.134), where Peet was having to chase Gunn for the review.
} 
on Egyptian numeration (Sethe 1916; Gunn 1916), and it is also unlikely - albeit conceivable - that Neugebauer might have been enquiring about Gunn's famous monograph on Egyptian syntax (Gunn, 1924).

\subsection{2. 'Journal of Egyptian Archaeology'}

The Journal of Egyptian Archaeology was the leading British journal of Egyptology, established in 1914 by the Egypt Exploration Society, and which is still published. At this date, it was sent out to elected members who paid a subscription (Egypt Exploration Society, 1919, pp. 10-11), and who had to be elected to the society. Neugebauer's question thus follows naturally on from the previous paragraph's enquiry about Gunn's work (if our hypothesis about the identity of this work is correct). From 1923 onwards, Peet was the editor, a fact apparently unknown to Neugebauer. The latter's name, however, does not appear as a subscribing individual in published lists for the years immediately following this letter; he is first listed as a member for 1940-1943 Egypt Exploration Society, 1943, p. 11) 35

\subsubsection{Professor Archibald and Dr Chace}

Neugebauer's passing reference to "the works of Prof. Archibald and Dr. Chace" suggests that he was aware of the forthcoming edition of the RMP by Chace which appeared in 1927 (see Section 1.1), and which incorporated a 'Bibliography of Egyptian mathematics with special references to the Rhind mathematical papyrus and sources of interest in its study' by R. C. Archibald. Peet was certainly aware of this new edition, having had correspondence about it with Chace (see below); moreover, he had had access to Archibald's bibliography since before the appearance of his own edition of the RMP (Peet, 1923a, Preface) 36

Raymond Clare Archibald (1875-1955) was a Canadian-American mathematician and historian of mathematics 37 He studied as an undergraduate at Harvard, before going on to the Universities of Berlin and Strasbourg (then Strassburg), obtaining a PhD in mathematics from the latter in 1900.

\footnotetext{
${ }^{35}$ Information thanks to Clare Lewis.

${ }^{36}$ The later offprint version of the bibliography that is held by the Peet Library is inscribed "Professor T. Eric Peet / with the cordial regards of R. C. Archibald / December, 1929".

${ }^{37}$ For biographies of Archibald, see Adams and Neugebauer (1955) and Sarton (1956); he does not feature in Bierbrier (2012).
} 
In 1908, he became an instructor at Brown University, where he remained for the rest of his career. Mathematically, Archibald's major interest was in mathematical tables, but he is best remembered for a variety of works in the history of mathematics: for example, on the history of the American Mathematical Society (Archibald, 1938). However, his historical work was not confined to the nineteenth and twentieth centuries, and in fact covered a vast chronological range (see Sarton 1956). Archibald's list of publications contains several items pertaining to ancient Greek mathematics, but the compilation of his annotated bibliography of sources relating to the RMP appears to have been a rare foray into detailed research linked to ancient Egyptian mathematics. As a further remark on Archibald, we note that at the end of the 1930s he was instrumental in arranging a post for Neugebauer at Brown (Siegmund-Schultze, 2016, pp. 90-91); moreover, Neugebauer and Sachs (1945) is dedicated to him as "Indefatiguable Student of the History of Mathematics, for Many Acts of Kindness and for Friendly Encouragement".

Arnold Buffum Chace (1845-1932) was an American cotton manufacturer and mathematician, and later Chancellor of Brown University ${ }^{38}$ After a trip to Egypt in 1910, he became interested in Egyptology, and soon purchased a copy of the British Museum's facsimile of the RMP (Budge, 1898). Over the following decade, he taught himself to read both hieroglyphs and hieratic, with the goal

that some day he would complete an edition of the papyrus for depositing in the Brown University Library, the consultation of which would enable one unfamiliar with hieratic to be able to find out what each symbol meant. (Archibald, 1933, p. 140)

To accompany his translations, Chace's wife, Eliza Greene Chace, copied the hieratic from the British Museum facsimile and produced the corresponding hieroglyphic transcriptions 39 His two-volume edition finally appeared in 1927 and 1929, ${ }^{40}$ having been completed with the assistance of Ludlow Bull of the Egyptian Department at the New York Metropolitan Museum of Art

\footnotetext{
${ }^{38}$ For biographies of Chace, see Koopman et al. (1932), Archibald (1933) and Bierbrier (2012, p. 113).

${ }^{39}$ Eliza Greene Chace did not live to see the completed edition; the first volume is dedicated to her (Chace, 1927/1929, vol. I, page before preface).

${ }^{40}$ Volume I features a free translation and commentary, while volume II contains photographs, transliteration, and a literal translation.
} 
and Henry Parker Manning, a retired mathematician at Brown. Earlier in the decade, Chace had in fact made contact with Peet and proposed a collaboration, even sending him portions of the incomplete manuscript. However, Peet declined over concerns about the quality of Chace's scholarship. ${ }^{41}$ Years later, after the publication of Chace's edition, Peet remarked to Gardiner, ${ }^{42}$ "Quite frankly, I found nothing of any value in Chace's publication of the Rhind except the photographs of the original ..."

Chace seems to have achieved his goal of producing an accessible version of the RMP, since his became the go-to edition of the RMP for mathematicians, who were perhaps discouraged by the philological detail of Peet's edition, as well as its lack of line-by-line translation. On the other hand, Chace's style did not always conform to the conventions employed by other Egyptologists: for example, transliterating Egyptian from right to left to match the direction of the original hieratic and hieroglyphic script. We note that much of the (polite but often lukewarm) review of Chace's edition that Peet wrote for The Mathematical Gazette focuses on differences of view between mathematicians and Egyptologists (Peet, 1930c).

\subsubsection{Sethe and his 'Untersuchungen zur Geschichte und Altertumskunde Aegyptens'}

'Untersuchungen zur Geschichte und Altertumskunde Aegyptens' ('Research on the History and Archaeology of Egypt') was a monograph series established by Neugebauer's teacher Sethe and later continued by Kees (see Section 1.2). It was started in 1896 with a text by Sethe himself (Sethe, 1896), and ended with volume 18, published in 1956 (Helck, 1956). Many of the early contributions were issued as short fascicles, a couple in each volume: by 1926, there had been eight volumes, comprising 16 separate texts. Neugebauer had links with Sethe, having studied with him (see Section 1.2), and having remained in correspondence with him after the latter's departure for Berlin in 1923 (Ritter, 2016, p. 135); indeed, Sethe is thanked in the preface to the dissertation for "eine Reihe wertvoller Bemerkungen und Berichtigungen in ägyptologischen Dingen" ( "a series of valuable remarks and corrections

\footnotetext{
${ }^{41}$ Expressed privately to Gardiner in, for example, a letter of 7 th December 1921: AHG/42.230.176.

${ }^{42}$ On 19th May 1930: AHG/42.230.39.
} 
in Egyptological matters": Neugebauer 1926, Vorwort), ${ }^{43}$ and was one of its examiners (along with Kees and Richard Courant: see Ritter 2016, p. 146). However, despite Neugebauer's claim to Peet, his dissertation was not published in Sethe's series, but by Springer in Berlin in 1926. ${ }^{44}$ We do not know the circumstances behind this apparent last-minute change of publisher ${ }^{45}$ but note that Springer would have been a perfectly natural choice for someone who was as closely involved in the Göttingen mathematical community as Neugebauer was — and it may tell us something about where Neugebauer saw his work as sitting within the wider literature, i.e., perhaps closer to mathematics than to Egyptology. In the years that followed, he seems to have developed a good working relationship with Julius Springer, and became founding editor of no less than four journals and monograph series published by Springer: 'Quellen und Studien zur Geschichte der Mathematik, Astronomie und Physik' (1929), Zentralblatt für Mathematik und ihre Grenzgebiete (1931), 'Ergebnisse der Mathematik und ihrer Grenzgebiete' (1932), and Zentralblatt für Mechanik (1933).

\subsubsection{Transliteration and layout}

Neugebauer followed the conventional transliteration of contemporaneous Egyptology, transliterating the Egyptian script into a modified Roman alphabet.46 Two Egyptian words/phrases are discussed in Neugebauer's letter to

\footnotetext{
${ }^{43}$ Sethe's remarks on the dissertation survive among Neugebauer's papers in Princeton: 'Dissertation, Maschinschriftexemplar mit Bemerkungen von Sethe', Otto Neugebauer Papers, Box 14, Shelby White and Leon Levy Archives Center, Institute for Advanced Study, Princeton, NJ, USA.

${ }^{44}$ The initial pre-publication version of the dissertation that earned Neugebauer his degree had been printed in Göttingen by the Dieterichsche Universitäts-Buchdruckerei.

${ }^{45} \mathrm{~A}$ remark at the end of the preface to the dissertation may hint at publishing difficulties: "Die Großzügigkeit des Verlages J. Springer hat schließlich das Erscheinen dieser Schrift überhaupt erst ermöglicht." ("It was only the generosity of the J. Springer publishing house that finally made the publication of this work possible." Neugebauer 1926 Vorwort)

${ }^{46}$ One, generally accepted, modern transliteration scheme is outlined in Imhausen 2007 . p. 9). Transliteration conventions often differ, for example, in their treatment of the voiced and the unvoiced $s$. Neugebauer used $s$ for an unvoiced $s$, as does the great Berlin Wörterbuch der ägyptischen Sprache (Erman and Grapow, 1926-1963), as well as Peet himself (1923, passim) and Gunn (1926, passim); $s$ is used for both the voiced and the unvoiced by much later and Anglophone Egyptology, including Gardiner's Egyptian grammar of 1927 (Gardiner, 1927). Imhausen (2003, p. 4) uses $s$ for the unvoiced and $z$ for the voiced.
} 
Peet. The first, skm, captures the notion of 'completion', and is discussed more fully in Section 2.3.6 below. The other, wzh tp $\mathrm{m}$, means 'to bow the head' in Middle Egyptian, and is used for 'to count with' (Peet, 1923a, pp. 1314) or 'add (cases or instances)' (Gunn, 1926, p. 124); the term features in many problems in the RMP. ${ }^{47}$

Turning from transliteration to layout, we note that Neugebauer's table (our Figure 6) presents an idealised version of the problems in the RMP. The papyrus was laid out using guide-lines to assist in the arrangement of the individual problems on the pages (see Section 1.1). Neugebauer characteristically schematised it (see the further remarks in Section 4). Ironically, Peet's edition of the RMP had been criticised by Gunn (1926, p. 137) for its failure to respect the original layout:

In the transcription considerable liberties have been taken with the original disposition of the calculations ... In sympathy, perhaps, with the scribe of Rhind, who had to squeeze his calculations between narrow rulings, $\mathrm{P}$ [eet] has allowed himself insufficient space, with unfortunate results.

\subsubsection{Egyptian fractions and Neugebauer's dissertation}

As we noted in Section 1.4, an understanding of the arithmetic of fractions is central to the interpretation of ancient Egyptian mathematics, a fact recognised by Neugebauer in his early work on this topic. Indeed, much of the content of his dissertation concerns fractional arithmetic: the second of his two chapters elaborates upon the role of fractions in ancient Egyptian mathematics, and picks up the topic of the construction of the $2 \div n$ table mentioned in Section 1.4. In his first chapter, on the other hand, Neugebauer attempted to provide a general characterisation of ancient Egyptian mathematics. In particular, he stressed its 'additive' nature: the idea that the ancient Egyptian scribe had no conception of general multiplication, merely the specific instances of multiplication (by 2, by 10) that we noted in connection with the two-column method, and that these were viewed as entirely separate operations. We will return to this point in Section 4 within the context of a discussion of Neugebauer's style of work. In the present subsection, we examine the technical details of the ideas that Neugebauer communicated

\footnotetext{
${ }^{47}$ Specifically: Problems 1-3, 5-6, 21-22, 26, 41-46, 50-52, 55-60, 65, and 69-70.
} 
to Peet. These details do appear in the dissertation, but in a much less concise form - in the letters, we see Neugebauer going to the heart of what he believed to be the key aspects of his work. We therefore do not provide a full survey of the content of Neugebauer's dissertation; this may be found in Ritter (2016, pp. 140-147).

The two parts of the $2 \div n$ table with which Neugebauer dealt in detail in his dissertation, and which are mentioned in his letter to Peet, are those concerning $2 \div 7$ and $2 \div 9$; we reproduce these portions of the RMP in Figures 7 and 8 , preserving the layout of the original as closely as possible. ${ }^{48}$ As we may see from the figures, these calculations appear in purely numerical form, without any verbal explanation, and therefore require a little unpicking. To take the case of $2 \div 7$, we notice the numbers $\overline{4}$ and $\overline{28}$ highlighted in bold at the top right of Figure $7{ }^{49}$ and observe further that in fact $2 \div 7=\overline{4} \overline{28}$. The rest of Figure 7 serves as a verification of this fact. Note that here (and throughout the rest of the $2 \div n$ table) the scribe did not reveal how he arrived

${ }^{48}$ See Peet (1923a, p. 38), where the layout was changed very slightly: cf. the facsimile in Chace (1927/1929, vol. II, Plates 2-3), and see also the discussion in Gunn (1926. pp. 126-127). In fact, Peet and Chace disagreed on the alignment of the columns in the calculation. Our Figure 7 and the explanation in the main text above are those of Peet, which incorporate a correction to what Peet believed was an error on the scribe's part: the $\overline{28}$ in the bottom row appears in the original as 28 , i.e., the fractional dot is missing, a common error throughout the papyrus. Chace, on the other hand, retained the 28 and aligned this under the $1 \overline{2} \overline{4}$ in the third row, so that the 4 at the beginning of the final row appears under the $\overline{4}$. Chace argued that this is then an instance of a type of double multiplication that he saw elsewhere in the papyrus: he suggested that ' 428 ' is a shorthand for the fact that ' 4 times 7 is 28 and $\overline{28}$ times 7 is $\overline{4}$ ' (Chace, $1927 / 1929$, vol. I, p. 17). This explanation by Chace seems to be an odd deviation from the usual two-column method, but so too is Peet's. Indeed, each explanation has its problems: we must either assume a scribal slip, or read more into the text than is actually written. Insofar as we can take it as a guide, the alignment of the text in the original papyrus seems to support Peet's interpretation over Chace's. That being said, Gunn's detailed discussion of this point leans more towards Chace's view (Gunn, 1926, pp.127-128). Gunn and Peet were experienced in the significant levels of scribal error in Ancient Egyptian manuscripts of various types.

${ }^{49}$ We note that all the row markers ' $\backslash$ ' appear in bold in Figures 7 and 8 , indicating that these are in red ink in the original. While the use of red ink for $\overline{4}$ and $\overline{28}$ in the representation of $2 \div 7$ (and for $\overline{6}$ and $\overline{18}$ in $2 \div 9$ ) presumably served to highlight the important parts of the calculation, the appearance of the row markers does not seem to have any significance, and probably means that the scribe simply forgot to change pens before making them. 
at this representation of $2 \div 7$ in the first place. In this case, however, the numbers appearing in Figure 7 open the door to some plausible speculation - this is not necessarily the case for the values elsewhere in the table, hence the debate over its construction that we noted in Section 1.4. In order to explain the calculations in Figure 7 , we observe that the $1 \overline{2} \overline{4}$ and the $\overline{4}$ that appear next to the bold $\overline{4}$ and $\overline{28}$, respectively, at the top right of the figure add together to make 2. On the left-hand side of the figure, the scribe then performed a division of 2 by 7 via the two-column method: he marked off the final two rows, where we find $1 \overline{2} \overline{4}+\overline{4}=2$ in the second column, and $\overline{4}+\overline{28}$ in the first, thereby verifying the claim that $2 \div 7=\overline{4} \overline{28}$. The only tricky aspect of the calculation is the fact that the scribe appears to have made a leap in writing down the row ' $\overline{28} \overline{4}$ '; we may speculate that this is simply something for which the scribe had an intuition, or had encountered before, or had derived via calculations and/or trials that are not recorded in the RMP. The left-most 4 of the bottom row was interpreted by Peet as indicating that 4 is the number by which we must multiply 7 in order to obtain 28; he cited the calculation in the centre of the figure as verification of this. The interpretation of the representation of $2 \div 9$ in the RMP, as found in our Figure 8, proceeds in a broadly similar way: at the top right, we find an indication that $2 \div 9=\overline{6} \overline{18}$, together with a decomposition of 2 as $1 \overline{2}+\overline{2}$. The latter is then used on the left-hand side within the division of 2 by 9 that verifies the asserted representation. In this instance, parts of the bottom row are lost in lacuna, but from the surviving traces, Peet asserted that "the reading is certain" (Peet, 1923a, p. 38; Pl. A, no. 9) 50

In his letter to Peet, Neugebauer sketched out the connection that he had drawn between the above divisions, and the set of problems within the RMP that Peet had labelled the 'first group of completions'. The term 'completion' appears here as the English translation of the Middle Egyptian skm, meaning 'to cause to be complete'. The word is used in the RMP in

\footnotetext{
${ }^{50}$ Again, the layout of Peet's version of this calculation is a little different from that in the original: cf. the facsimile in Chace (1927/1929, vol. II, Plate 3). Moreover, despite Peet's certainty, he and Chace differed in their reconstruction of the final row: Chace had this as '2 $18 \quad \overline{2}$ ', with the initial 2 sitting under the $\overline{6}$ in the row above. He then read this as the same type of double multiplication as indicated in footnote 48 above. Peet's reconstruction seems to us to be the simpler and the more convincing, and while Chace's edition is based on the published facsimile, Peet's transcription was collated with the original (Peet, 1923a, p. 136).
} 


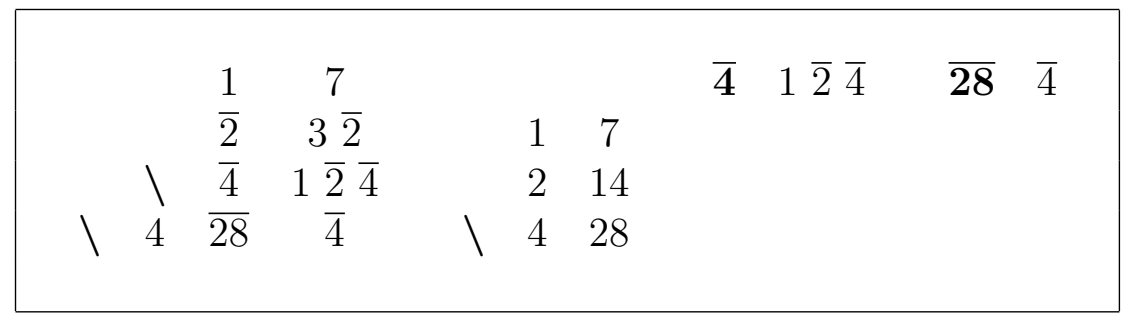

Figure $7: 2 \div 7$ in the RMP; bold print indicates red ink in the original.



Figure $8: 2 \div 9$ in the RMP; bold print indicates red ink in the original; square brackets enclose reconstructed portions.

connection with Problems 21-23, where it indicates a "process amounting to simple subtraction" (Peet, 1923a, p. 12) — we have already seen an example of such a process in RMP Problem 23, as found in Figure 2. The same word skm was applied also to a rather different collection of problems, namely 7-20; as Peet (1923a, p. 13) noted:

[t]hat this is not specifically a word for subtraction is clear from the examples Nos. 7-20, where it is used of making one quantity up to another by the addition of aliquot parts of itself. ${ }^{51}$

Peet therefore distinguished between Problems 7-20 as the 'first group of completions' (Peet, 1923a, pp. 53-58) ${ }^{52}$ and Problems 21-23 as the 'second

\footnotetext{
${ }^{51}$ This is broadly the same explanation as that previously given by Eisenlohr $1877 / 1891$, vol. I, p. 53): "In Nr. 7-20 ist darunter die Ergänzung eines einfachen oder zusammengesetzten Bruches durch Addition von Vielfachen dieses Bruches zu einem Ganzen oder zu einem einfachen Bruche verstanden ..." ("In Nr. 7-20, $[\mathrm{skm}]$ is understood to mean the completion of a simple or compound fraction to a whole or a simple fraction via the addition of multiples of that [the initial] fraction ...")

${ }^{52}$ The first group of completions also contains a Problem 7B, which is a duplicate of
} 


\begin{tabular}{|c|c|}
\hline Problem & Result \\
\hline $7=7 \mathrm{~B}=10$ & $\overline{4} \overline{28} \times 1 \overline{2} \overline{4}=\overline{2}$ \\
8 & $\overline{4} \times 1 \overline{\overline{3}} \overline{3}=\overline{2}$ \\
$9^{*}$ & $\overline{2} \overline{10} \times 1 \overline{2} \overline{4}=1$ \\
11 & $\overline{7} \times 1 \overline{2} \overline{4}=\overline{4}$ \\
12 & $\overline{14} \times 1 \overline{2} \overline{4}=\overline{8}$ \\
13 & $\overline{16} \overline{112} \times 1 \overline{2} \overline{4}=\overline{8}$ \\
$14^{*}$ & $\overline{18} \times 1 \overline{2} \overline{4}=\overline{16}$ \\
$15^{*}$ & $\overline{32} \overline{228} \times 1 \overline{2} \overline{4}=\overline{16}$ \\
16 & $\overline{2} \times 1 \overline{\overline{3}} \overline{3}=1$ \\
17 & $\overline{3} \times 1 \overline{\overline{3}} \overline{3}=\overline{\overline{3}}$ \\
18 & $\overline{6} \times 1 \overline{\overline{3}} \overline{3}=\overline{3}$ \\
19 & $\overline{12} \times 1 \overline{\overline{3}} \overline{3}=\overline{6}$ \\
20 & $\overline{24} \times 1 \overline{\overline{3}} \overline{3}=\overline{12}$ \\
\hline
\end{tabular}

Table 1: Summary of the first group of completions in the RMP; the problems marked with an asterisk are incorrect, due to errors in copying the figures.

group of completions (Peet, 1923a, pp. 58-60)

The first group of completions may be divided into two types, depending on the aliquot parts that are used: Problems 7 and 9-15 involve the multiplication of a given number by $1 \overline{2} \overline{4}$, while Problems 8 and $16-20$ entail multiplication by $1 \overline{\overline{3}} \overline{3}$ (which is of course equivalent to doubling — we will return to this point below). A summary of the first group of completions is

Problem 7; indeed, Problem 10 is also a duplicate of Problem 7.

${ }^{53}$ Since the term $\mathrm{skm}$ appears within the first group of completions only at the beginning of Problem 7 ('Example of completion'), Chace (1927/1929, vol. I, p. 23) argued that it is in fact an error - that the scribe wrote this down as a heading for Problems 21-23, but then realised that other problems should precede these. Peet also found it "surprising" that skm should be used in two such different ways (Peet, 1923a, p. 53), although Gunn (1926, p. 130) argued that they are not so different. On the term $s k m$, see Imhausen (2003. pp. 54-57), although, as we noted in Section 1.1, she omits the first group of completions (the second group may be found in Imhausen 2003, pp. 203-205). 


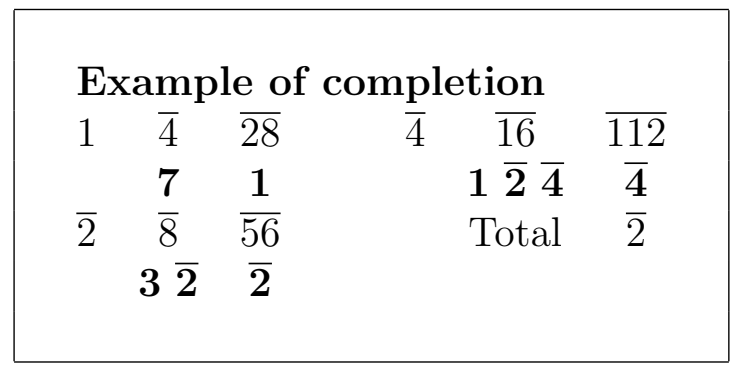

Figure 9: Problem 7 from the RMP; bold type indicates red ink in the original.

given in Table $1{ }^{54}$ Since Neugebauer's letter to Peet focuses on the problems involving multiplication by $1 \overline{2} \overline{4}$, we give the first of these (Problem 7 ) in Figure 9 as an example of this type of completion. Problem 7 also has the benefit of being one of the problems in which the scribe gave a reasonably full indication of the underlying methods. 55

Although the scribe laid out the problem in a slightly odd way, Problem 7 of the RMP works in much the same manner as the problems that we have considered previously. The scribe began with the initialisation ' $1 \overline{4} \overline{28}$ ', then halved this twice to obtain the rows ' $\overline{2} \quad \overline{8} \overline{56}$ ' and ' $\overline{4} \quad \overline{16} \overline{112}$ ', the latter appearing to the right, rather than under the preceding rows. Although no row markers appear, the scribe then sought to add together all of the rows, namely to compute the product of $\overline{4} \overline{28}$ and $1 \overline{2} \overline{4}$. In order to do this, he used the method of red auxiliaries that we outlined in Section 1.4. Taking 28 as his reference number, he noted down the red auxiliaries that appear in bold in Figure 9. These add together to make 14, from which the scribe deduced his overall answer of $\overline{2}$. The other problems within the first group of completions are presented in a broadly similar layout, and appear to proceed in much the same manner, although the scribe did not record the red auxiliaries in all cases ${ }^{56}$ perhaps for the simple reason that the method was not necessary in

\footnotetext{
${ }^{54}$ By way of correcting the erroneous problems, Peet (1923a p. 55) suggested that the $\overline{10}$ in Problem 9 should be $\overline{14}$, and that the $\overline{228}$ in Problem 15 should be $\overline{224}$, while Chace $(1927 / 1929$, vol. I, p. 64$)$ replaced the $\overline{18}$ in Problem 14 by $\overline{28}$.

${ }^{55}$ Peet's version of Problem 7 can be found in Peet (1923a, p. 54); see Chace $(1927 / 1929$ vol. II, Plate 39) for Chace's.

${ }^{56}$ Specifically, full sets of red auxiliaries appear within Problems 7, 8, 13-15, 19 and 20; Problem 7B features auxiliaries for just one row, but no such numbers appear within the remaining problems.
} 
those instances (see Section 4 for Peet's comments on one such case).

In his letter to Peet, Neugebauer outlined the systematic approach that he had taken to those problems within the first group of completions that involve multiplication by $1 \overline{2} \overline{4}$. He asserted that these form a "related table", constructed via a "simple transmission scheme"; the version of this table that Neugebauer drew out for Peet appears here as our Figure6. In Neugebauer's view, there is one "original" calculation within this collection of problems, namely that given in Problem 11: $\overline{7} \times 1 \overline{2} \overline{4}=\overline{4}$. If we approach this calculation via the method of red auxiliaries and take 28 as our reference number, as the scribe certainly did for Problem 7, then we find that the auxiliaries are all integers. Although the scribe either did not use or did not record auxiliaries for Problem 11, Neugebauer nevertheless inserted them in square brackets into the appropriate places in Figure 6. As he pointed out, the derivation of the closely-related Problems 12 and 14 then proceeds in an "entirely schematic" manner: since Problem 12 involves $\overline{14}$, we simply halve every number appearing in Problem 11 (once again inserting auxiliaries that do not appear in the papyrus), and then halve again to arrive at Problem 14. Recall that the statement of the latter is incorrect in the original papyrus, but Neugebauer incorporated a correction by writing $\overline{28}$ in place of $\overline{18}$. This problem does feature auxiliaries, and these are consistent with the corrected version - hence Neugebauer's remark about the meaning of the "seemingly purposeless auxiliary numbers".

The bottom half of Figure 6 features a further series of schematic derivations which take Problem $7(\overline{4} \overline{28} \times 1 \overline{2} \overline{4}=\overline{2})$ as their original. Doubling all of the numbers involved yields a corrected version of Problem $9(\overline{2} \overline{14} \times 1 \overline{2} \overline{4}=$ $1)$, while repeated halving results in Problem $13(\overline{16} \overline{112} \times 1 \overline{2} \overline{4}=\overline{8})$ and a corrected Problem $15(\overline{32} \overline{224} \times 1 \overline{2} \overline{4}=\overline{16})$, via an interpolated Problem 11b $(\overline{8} \overline{56} \times 1 \overline{2} \overline{4}=\overline{4})$ that does not appear in the papyrus $\sqrt{57}$ As the arrows in Figure 6 indicate, there is a natural connection between the top and bottom halves of the table, namely that between Problems 11 and 7 . We recall from Figure 7 that $\overline{4} \overline{28}$ is a representation of $2 \div 7$ in terms of unit fractions, and so Problem 7 might be recast as a calculation involving the quantity $2 \div 7$, i.e., a doubling of the quantity that is the subject of Problem 11. However, Neugebauer's transmission scheme does not seem to extend to a means of linking the top and bottom halves of Figure 6 in a systematic manner: for

\footnotetext{
${ }^{57}$ Concerning both of the corrections mentioned here, see footnote 54 above.
} 


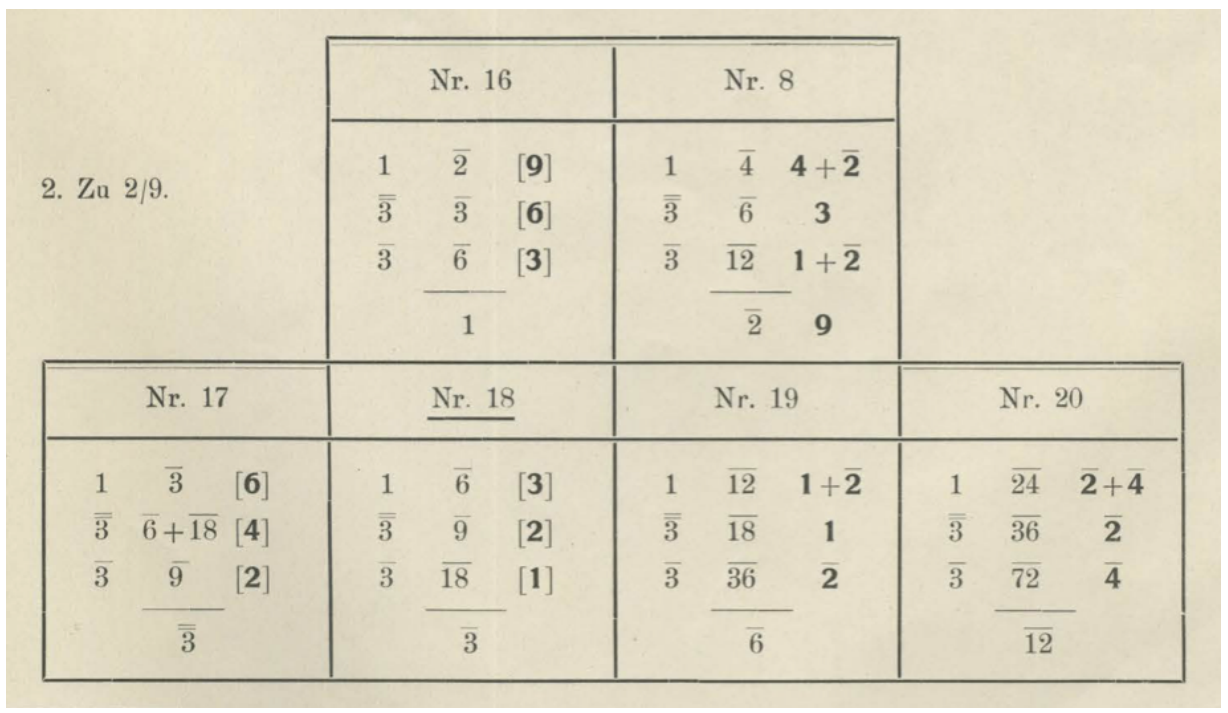

Figure 10: Neugebauer's linking of Problems 8 and 16-20 of the RMP with the representation of $2 \div 9$ as a sum of unit fractions.

example, the $\overline{8} \overline{56}$ in Problem 7 is equal to $\overline{7}$, but there does not seem to be a natural way within this scheme of connecting the former with the $\overline{14}$ to which it would need to correspond in Problem 11.

Going beyond the simple linking of problems within the first group of completions, Neugebauer's dissertation offers the transmission scheme above as a means of constructing the values in the $2 \div n$ table on a systematic and purely additive basis, in line with his observations about the fundamental nature of ancient Egyptian mathematics. In the case of $2 \div 7$, he saw Problem 7 as being preparatory to the representation of $2 \div 7$ as a sum of unit fractions: recall from Figure 7 that the value $1 \overline{2} \overline{4}$ appears within the process of deriving the representation $2 \div 7=\overline{4} \overline{28}$. In a very similar way, he proposed that the remaining problems within the first group of completions, i.e., those involving multiplication by $1 \overline{\overline{3}} \overline{3}$, may also be linked together and viewed as preparation for the representation of $2 \div 9$ as a sum of unit fractions: the table that he presented in his dissertation appears here as our Figure $10{ }^{58}$

\footnotetext{
${ }^{58}$ This is Table III.2 of Neugebauer (1926); on the same page, Table III.1 is a printed version of our Figure 6. We believe that the hand-drawn version of the table that Neugebauer sent to Peet is rather easier to understand, in particular because of the dynamic sense afforded by the arrows. A version of the table that incorporates the whole of the
} 

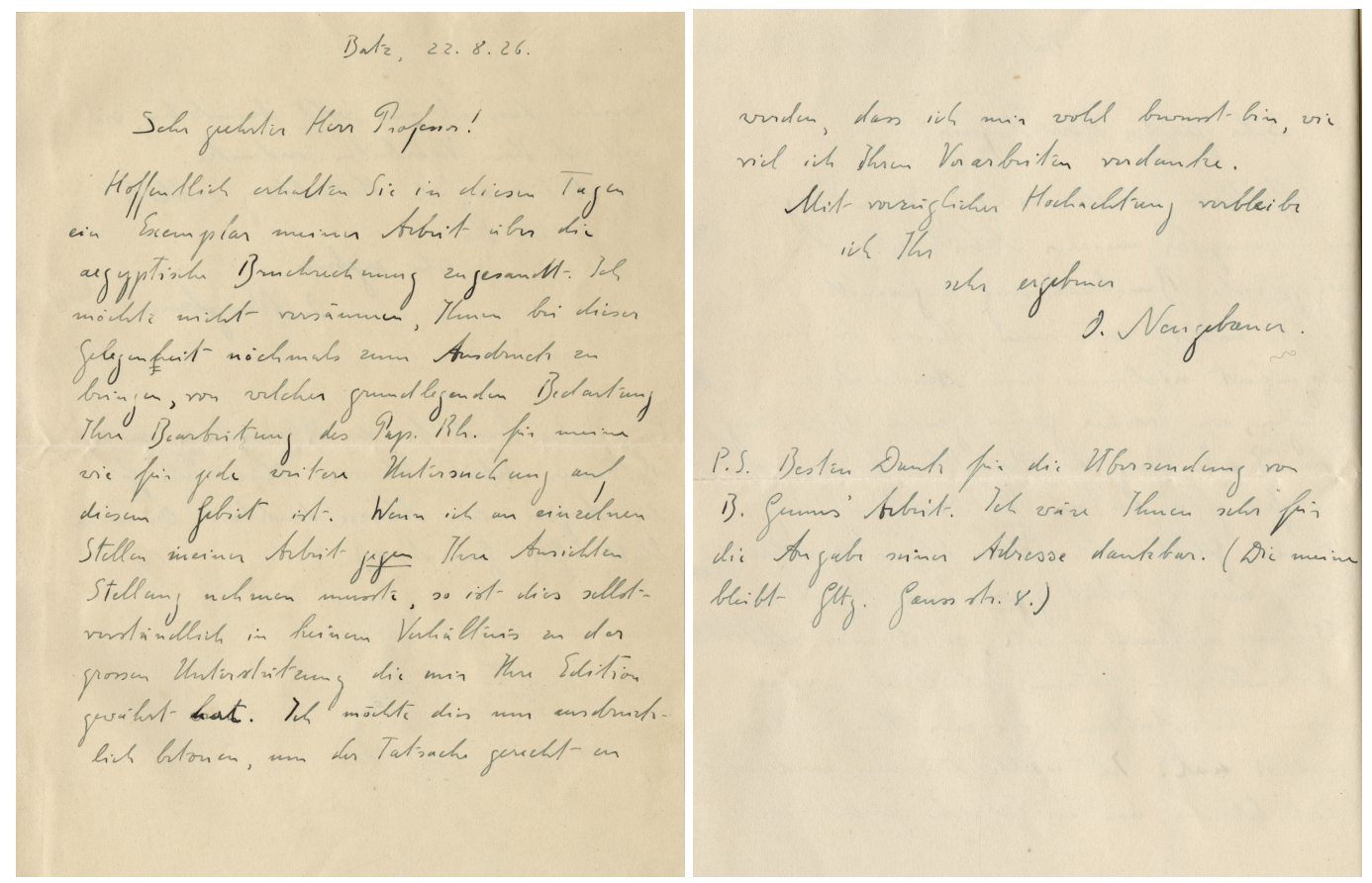

Figure 11: Letter of 22nd August 1926.

Neugebauer believed that he had demonstrated that the so-called first group of completions served as groundwork for the representations of $2 \div 7$ and $2 \div 9$ : that they in some sense formed part of the 'completion' of these representations - hence his remark to Peet that "[t]he name śkm is completely justified". In his dissertation, he went on to offer suggestions as to how the rest of the $2 \div n$ table might have been constructed on the additive basis, but we will not go into this here. In Section 4, we will consider what Peet (and others) thought of Neugebauer's ideas.

\section{Letter of 22nd August 1926}

This letter is written on paper of the same colour and texture as the first. It consists of a single sheet, measuring $15.7 \times 19.4 \mathrm{~cm}$, apparently cut down from one of the larger sheets. Perhaps because of this trimming, no watermark is present. Unlike the first letter, which was simply inserted

first group of completions may be found in Neugebauer (1969, p. 140). 
between the pages of Peet's copy of Neugebauer's dissertation, this letter was pasted along one edge onto the initial blank page of the volume.

\subsection{Transcription}

Batz, 22.8.26.

Sehr geehrter Herr Professor!

Hoffentlich erhalten Sie in diesen Tagen ein Exemplar meiner Arbeit über die aegyptische Bruchrechnung zugesandt. Ich möchte nicht versäumen, Ihnen bei dieser Gelegenheit nochmals zum Ausdruck zu bringen, von welcher grundlegenden Bedeutung Ihre Bearbeitung des Pap. Rh. für meine wie für jede weitere Untersuchung auf diesem Gebiet ist. Wenn ich an einzelnen Stellen meiner Arbeit gegen Ihre Ansichten Stellung nehmen musste, so ist dies selbstverständlich in keinem Verhältnis zu der grossen Unterstützung die mir Ihre Edition gewährt hat. Ich möchte dies nur ausdrucklich [sic] betonen, um der Tatsache gerecht zu [2] werden, dass ich mir wohl bewusst bin, wie viel ich Ihren Vorarbeiten verdanke.

Mit vorzüglicher Hochachtung verbleibe

ich Ihr

sehr ergebener

O. Neugebauer.

P.S. Besten Dank für die Übersendung von B. Gunns Arbeit. Ich wäre Ihnen sehr für die Angabe seiner Adresse dankbar. (Die meine bleibt Gttg. Gaussstr. 8.)

\subsection{Translation}

Batz, 22.8.26.

Dear Professor,

Hopefully in these days you will receive a copy sent to you of my work on Egyptian fraction reckoning. I would not like to miss this opportunity to reiterate to you the fundamental importance of your edition of the Rhind papyrus for my as for any further investigation in this field. If I have had to take a stand against your views at certain points of my work, this is of course disproportionate to the great support that your edition has given me. 
I would like only to emphasise this explicitly in order to acknowledge the fact [2] that I am well aware how much I owe to your preliminary work.

With the greatest respect I remain

your very devoted

O. Neugebauer.

P.S. Many thanks for sending B. Gunn's work. I would be very grateful to you for giving his address. (Mine remains Göttingen Gaussstr. 8.)

\subsection{Notes}

Since it is so short, there is much less to say about this letter than the first, although it appears to have been important enough to Peet that he pasted it into the front of his copy of the dissertation. Peet's edition of the RMP, and Neugebauer's assessment of it, has stood the test of time. The same superlatives that appear in Neugebauer's letter (and which began in his review of Peet's edition) may be found in more recent works on ancient Egyptian mathematics: Imhausen (2016, p. 66), for example, refers to its "excellent quality".

Picking up from Section 2.3.1 regarding Gunn, we note that despite Neugebauer's efforts here to obtain Gunn's address, we do not know whether they ever corresponded. Gunn was working in Egypt at Saqqara in 19241927 (Bierbrier, 2012, p. 232), and spending his summers at least partly in Vienna with his family (see, for example, Hughes 1946, p. 184, Hughes 1951, p. 10): keeping track of Gunn's address seems to have been a challenge even for his friends and close collaborators 59

The apology that appears in Neugebauer's letter probably refers to his stance on the status of the first group of completions as being preparatory to the calculation of $2 \div 7$ and $2 \div 9$, as described in Section 2.3.6. Peet's interpretation of these problems was rather different and of much less definite purpose: for him, these problems were simply examples of Egyptian experimentation with numbers, in search of useful quantities and relationships. He

\footnotetext{
${ }^{59}$ The earlier letter from Peet to Gardiner that we cited above in footnote 34 features an appeal for an up-to-date address for Gunn, to which Gardiner responded: "I have been bombarded with enquiries after Gunn's address, one of the bombardiers being his mother. He is not in Vienna but was recently seen in Venice. I imagine he will be going back to Sakkhara soon, that he can be got at there. But if you succeed in getting your review out of him you will be clever." (AHG/42.230.133, Gardiner to Peet, 14th October 1924)
} 
remarked:

What the Egyptian actually did was to experiment with various quantities, adding either their half and their quarter, or their third and their two-thirds, and recording the result as valuable when it happened to be an aliquot part. In fact, we are here [in the first group of completions] face to face with some of those actual experimental methods on which so much of Egyptian mathematics is based. We are not solving set problems but discovering by trial useful facts for future use. (Peet, 1923a, p. 54)

In Section 1.4, we observed that a practiced scribe would perhaps have developed an ability to apply the method of the red auxiliaries in such a way that either integers or simple or dimidiated fractions would result. It seems plausible that the necessary intuition might have been developed via the type of experimentation that Peet suggested here: it is certainly the case that nearly every result within the first group of completions is a dimidiated fraction; those that are not are simple aliquot parts $(\overline{3}, \overline{6}, \overline{12})$ or the special fraction $\overline{\overline{3}}$. We may speculate further that even the errors in the first group of completions (see Table 1) result from wishful thinking on the part of a scribe who was searching for dimidiated fractions. To pick up on a point made in Section 2.3.6. Peet saw the scribe's (deliberate?) ignoring of the fact that multiplying by $1 \overline{\overline{3}} \overline{3}$ is equivalent to doubling (Problems 8 and 16-20) as "a further testimony to the experimental nature of these calculations" (Peet, 1923a, p. 55) 60

A final point of interest in this letter is that it was sent not from Göttingen, but from 'Batz', meaning Batz-sur-Mer on the Atlantic coast of France. This is the seaside resort to which some Göttingen mathematicians - at least those linked to P. S. Aleksandrov - famously decamped during the summer months, and which features strongly within the mythology of Göttingen mathematics. It appears, for example, in the memoirs of Aleksandrov (1979), in passages concerning his visits to Göttingen during the 1920s, and was the

${ }^{60}$ Gunn (1926, p. 130), however, disliked Peet's suggestion regarding the scribe's multiplication by $1 \overline{\overline{3}} \overline{3}$, and preferred to see these problems as preparatory calculations for a table, a view shared by Imhausen (2003, p. 54), who for that reason omits them entirely from her analysis of the structure of ancient Egyptian mathematical problems. More generally, the experimental aspect of ancient Egyptian mathematics is supported by Imhausen (2016, p. 96), particularly in connection with the construction of the $2 \div n$ table. 
place where his friend and fellow-mathematician P. S. Uryson drowned in the summer of 1924 (Aleksandrov, 1950). Elsewhere in his memoirs, Aleksandrov recorded that the summer of 1926, the year of Neugebauer's letters to Peet, was the occasion of his befriending both Heinz Hopf and Neugebauer in Göttingen; indeed, in a memoir of Hopf, he explicitly recalled a trip to Batz with them that summer (Aleksandrov, 1976/1977, p. 119). Thus, while these letters from Neugebauer to Peet demonstrate the former's attempts to integrate himself into the wider Egyptological community, we see from them that he nevertheless remained firmly embedded in the Göttingen mathematical circle — both socially and, as we shall discuss in Section 4 , mathematically.

\section{Concluding remarks}

As often in archival work, we have been able only to present one side of this correspondence, though Neugebauer's thanks for an earlier letter from Peet (see the beginning of the letter of 12th April 1926) indicates that it was indeed a two-way correspondence ${ }^{61}$ However, to the best of our knowledge, the other half has not survived: it does not appear to be among the Neugebauer Papers at the Institute for Advanced Study in Princeton, NJ, and may indeed have been destroyed, since there are indications that Neugebauer burnt much or all of his correspondence. ${ }^{62}$ Likewise, there do not appear to be any further letters from Neugebauer to Peet in other archives in Oxford. However, we may still gain an indication of Peet's reaction to Neugebauer's work by examining letters of his that are held in the Griffith Institute Archive - in particular, letters to Gardiner. One of these, dated 16th October 1926, includes the following:

You have probably received Neugebauer's Die Grundlage [sic] der äg. Bruchrechnung. I have had much correspondence with him while he has been working on it. Frankly I don't even now fully follow his demonstration that the skm-reckonings prepare the way for the resolutions of $2 / 7$ and $2 / 9$, though I think he is right, and

\footnotetext{
${ }^{61}$ We note, moreover, that Neugebauer continued to send his work to Peet: the copy of Neugebauer (1930) that is held in the Peet Library is inscribed from Neugebauer to Peet.

${ }^{62}$ See the remarks in Siegmund-Schultze (2016, pp. 63-64), and also in Lewis Pyenson's biography of Neugebauer for American National Biography: https://doi.org/10.1093/ anb/9780198606697.article.1302474 (accessed 27th April 2020).
} 
I shall doubtless agree after I have read him more carefully. I am inclined to think he exagerates $[$ sic $]$ the "additiv" character of Egyptian maths, but even about this I am not quite clear as yet. In any case his is an admirable piece of work ... [I]t has served to re-open the study of Egyptian maths 63

Neugebauer's name appears elsewhere in the correspondence between Peet and Gardiner, usually in a neutral tone, although he is at one point criticised (along with certain other historians of ancient mathematics) for writing letters that "get more abstruse each time".64 On the other hand, Neugebauer is praised in passing for his work on the history of mathematics (and in much the same company) in a book review that Peet wrote some years later (Peet, 1934a, p. 120). Elsewhere, Peet described Neugebauer's dissertation as "enlightening if difficult" (Peet, 1930a, p. 270). Thus, although Peet may have had some initial concerns about certain of the details of Neugebauer's work on ancient Egyptian mathematics, he does not appear to have doubted his abilities as a scholar.

A further indication of Peet's views on Neugebauer's work may be gained from his copy of the dissertation now in the Peet Library: as with many of his books, Peet annotated the dissertation. These annotations consist mostly of underlinings, with the occasional question mark in the margin, from which it is difficult to draw firm conclusions. The marginal notes next to Neugebauer's discussion of the first group of completions are largely arithmetical: in particular, Peet rewrote some of Neugebauer's renderings of RMP problems in traditional fractional notation, rather than the new ' $\bar{n}$ ' notation used in the dissertation. A hint of the initial doubts that Peet expressed to Gardiner may be seen in the margin next to the passage where Neugebauer began to link Problems 7 and 9-15 with the calculation of $2 \div 7$ (Neugebauer, 1926, p. 28): here, Peet wrote simply "But why [sic]"; it is not clear whether this question refers to the passage as a whole, or specifically to Neugebauer's claim that Problems 12 and 14 follow schematically, which Peet underlined (among other things). Within the same paragraph, Neugebauer asserted that the decomposition $\overline{4} \overline{28}$ for $2 \div 7$ must also be derivable (or at least verifiable) via the method of red auxiliaries, and proceeded to suggest the way in which an ancient Egyptian scribe would have done this. Implicitly taking 28 as the

\footnotetext{
${ }^{63}$ AHG/42.230.92(2), Peet to Gardiner, 16th October 1926.

${ }^{64} \mathrm{AHG} / 42.230 .39$, Peet to Gardiner, 19th May 1930.
} 
reference number, he stated: "Dann muß also $\overline{28}$ die Hilfszahl 1 bekommen, $\overline{4}$ die Hilfszahl 7 wie es in Nr. 7 geschieht" ("Then $\overline{28}$ must get the auxiliary number $\mathbf{1}, \overline{4}$ the auxiliary number $\mathbf{7}$, as happens in Nr. 7"). Here, Peet circled the word "muß" ("must") and wrote "Why?" in the margin. It is not clear exactly what Peet was querying here: perhaps the implicit assumption that the scribe would automatically take 28 as a reference number? We suggest that Peet was not necessarily questioning the content of Neugebauer's assertion, but its certainty, which contrasted strongly with Peet's own more cautious way of working.

Turning briefly to other contemporary opinions of Neugebauer's dissertation, we observe that its published form garnered a rather large number of mostly mathematical reviews. ${ }^{65}$ Many of these are largely descriptive, but we note here one evaluative review: the short passage (Chace, 1927/1929, vol. I, pp. 189-190) that appears in Archibald's bibliography of sources relating to the RMP (see Section 2.3.3). This describes Neugebauer's dissertation as a "[t]houghtful and interesting monograph ... showing considerable insight into the spirit of Egyptian mathematics". Archibald appears to have been convinced by Neugebauer's 'completion' of $2 \div 7$ via Problems 7 and 9-15, but noted that Neugebauer has made the case for $2 \div 9$ "[l] ess clearly". We perhaps also see a mild criticism in Archibald's review: that Neugebauer "[did] not indicate the most natural explanation of the way in which [the $2 \div n$ ] table was formed" - this assumes, of course, that there was a uniform method, something that is by no means clear (see the remarks at the end of Section 1.4).

To pick up on the major feature of Neugebauer's work that was noted by Peet in the quotation at the beginning of this section, it is certainly the case that Neugebauer emphasised the 'additive' nature of ancient Egyptian mathematics very strongly in his dissertation, even going so far as to describe it as being of "the utmost importance for the understanding of Egyptian mathematics" ${ }^{66}$ and making it the central theme of the first of his

\footnotetext{
${ }^{65}$ JFM 52.0004.02; Norsk Mat. Tidsskrift 8 (1926), 142-144; Bull. Amer. Math. Soc. 33(3) (1927), 371; Orient. Lit. Berlin 30 (1927), 471; Z. math. Unterricht 58 (1927), 43; Arch. Geschichte Math. Naturwiss. Tech. 10 (1927), 233-237; Math. Gaz. 14(195) (1928), 198; Monatsh. Math. Phys. 36(1) (1929), A3; Jahresber. Deutsch. Math.-Verein. 38 (1929), 88 kursiv.

66 "Für das Verständnis der ägyptischen Mathematik ist diese Eigentümlichkeit von größter Bedeutung." (Neugebauer, 1926, pp. 1-2)
} 
two chapters. Given the instances of doubling, halving, inversion, etc., that we saw in Section 1.4, it may be something of a simplification to say that Egyptian arithmetic was 'purely additive', and yet we find no major errors in Neugebauer's analysis. This being said, however, the 'additive' point of view is not prominent in subsequent accounts of this topic, such as that most recently by Imhausen (2016). We might speculate, therefore, that this was very much the concern of a mathematician on Neugebauer's part: what he said may be true, but it is perhaps not the major feature of ancient Egyptian arithmetic that he assumed. Indeed, Peet's responses suggest exactly this: that he believed Neugebauer, but that he felt that the latter's emphasis was misplaced. Other opinions may be found in contemporaneous reviews of the dissertation: for example, the mathematician Heinrich Wieleitner commented: "ich halte all das nicht für falsch, aber die ganze Auffassung für zugespitzt und übertrieben" ("I do not think this is wrong, but the whole view is pointed and exaggerated": Wieleitner 1927, p. 234), while the historian of mathematics Florian Cajori felt that Neugebauer had argued well for the possibility of establishing arithmetic on an additive basis, but that he had not demonstrated that this was what the ancient Egyptians actually did (Cajori, 1927). The notion of an additively-based mathematics was a theoretically-appealing construction, consistent with the available evidence, but was one that had not been, and perhaps could not be, proved.

This last point brings us naturally to a few remarks on Neugebauer's style of work, as represented by the ideas that he put forth in his dissertation, and which he communicated to Peet in these letters. On the Egyptological side, having studied with Sethe and Kees, Neugebauer was part of the philological tradition of German Egyptology, with its focus on texts, and lesser concern for archaeological context - a precursor perhaps of the 'cross-cultural' approach to the history of mathematics. His mathematical training also placed him firmly in the Göttingen mathematical school, with its concern for rigorous foundations and general principles. The systematisation and idealisation that we see in Neugebauer's approach to the RMP, and his assertion of the overarching additive principle, are not only characteristic of this background, but also of Neugebauer's subsequent work in the history of the exact sciences, where the emphasis was on the 'exact', and where we often find schematics such as that which he sent to Peet ${ }^{67}$ As Rowe $(2012$, p. 34) has noted,

\footnotetext{
${ }^{67}$ See, for example, the various tables in Neugebauer (1930). We note that this style
} 
"Neugebauer's special métier was that of a mathematical detective, one who went about combing artifacts for underlying patterns" 68 As we have seen, this striving for patterns meant that Neugebauer was not above interpolating whole new problems in the RMP (Problem 11b) or inserting auxiliary numbers that do not appear in the original text (more on this below). This attitude is parallel in Egyptology to the 'Berlin school' of philology, which tried to reconstruct the archetype of a text through emendation (see, for example, Parkinson 2009, pp. 237, 241). That the derivation of such patterns and principles was viewed by Neugebauer himself as the key feature of his work is suggested by the fact that he communicated these ideas to Peet in advance of sending him a copy of the dissertation. That such an approach to historical mathematics was viewed positively by the wider mathematical community is hinted at by Ludwig Bieberbach (1929) in his review of Neugebauer's dissertation:

Es ist erfreulich zu sehen, wie die Geschichte der Mathematik unter den Händen einiger Forscher allmählich aus dem Stadium der Reportage oder Chronik zur Wissenschaft erhoben wird. Gerade das moderne Interesse an Grundlagenfragen scheint den Blick der Forscher auch für historische Zusammenhänge und das historische Urteil zu schärfen. (It is gratifying to see how the history of mathematics, in the hands of some researchers, is gradually being elevated from the stage of reportage or chronicle to science. In particular, the modern interest in fundamental questions seems also to sharpen the view of researchers for historical connections and historical judgement.)

If Neugebauer already had good standing with mathematicians, then what we see in these letters is him attempting to integrate himself into the wider Egyptological community. He presumably already had links to the wider German-speaking community via Kees and Sethe, but here he sought to make a connection with English-speaking counterparts by reading Gunn's

of working was probably original to Neugebauer, and then reinforced by his Göttingen education: Ritter (2016, p. 130) presents a diagram drawn by Neugebauer in 1921 (i.e., prior to his Göttingen days) in which he attempted to systematise certain ideas relating to General Relativity.

${ }^{68}$ On Neugebauer's approach to the study of ancient mathematics more generally, see Rowe (2012, 2016). 
work, by seeking a subscription to the Journal of Egyptian Archaeology, and ultimately by joining the Egypt Exploration Society.69 Despite clear differences between his style of work and that of contemporary professional Egyptologists, he still saw the value in making the connection. Moreover, as we have seen (see Section 3.3 and the further comments below), he was not afraid to disagree with his correspondents (however politely); the ideas that he communicated to Peet were rather better received than his views on the Sothic cycle some years later (Ritter, 2016, pp. 153-155).

The fact that we see Peet and Neugebauer, two veterans of opposite sides of the First World War, apparently communicating so easily in 1926 is in part a sign of the international importance of German scholarship in Egyptology, and especially in textual studies, although the tensions and complexities in the Egyptological networks of this period are not fully studied.70 In contrast, the situation in mathematics has been fairly well documented (see, for example, Lehto 1998), so we know that by 1926 Germany was slowly being readmitted to international mathematical activities, following the Locarno Agreement of the preceding year.

To revisit the points upon which Peet and Neugebauer disagreed in their analysis of problems from the RMP, we note that this again seems to have been linked to the latter's search for uniform methods within the papyrus. We have seen (Figure 6) how Neugebauer had inserted red auxiliaries into places where the original scribe had not, as part of his assertion that all of the problems in the first group of completions were solved in the same manner, namely via the method of auxiliaries. In Peet's view, however, the problems were solved by a mixture of methods. In the case of Problem 16, for example, he did not see the absence of red auxiliaries as an omission on the part of the scribe, but as something that simply was not necessary: "[t]he example is so simple that the addition of the three fractions $[\overline{2}, \overline{3}$ and $\overline{6}]$ is achieved without the use of a common denominator" (Peet, 1923a, p. 57). It may be that in his drive to uncover a uniform method of calculation, Neugebauer simply failed to recognise that, as Peet believed, the addition $\overline{2}+\overline{3}+\overline{6}$ would not have caused any difficulty for an experienced scribe and therefore did not require the more advanced method of red auxiliaries, or the insertion of elements not present

\footnotetext{
${ }^{69}$ Neugebauer's links with Assyriologists are perhaps a little better documented, having been dealt with in more detail in several chapters of Jones et al. (2016).

${ }^{70}$ For an initial contribution to this story, see Lewis (2014); for an overview of Egyptology in this period, see Thompson (2018).
} 
in the original text. Neugebauer's explanation represents a mathematician's idealisation of this collection of problems, rather than an assessment of how such problems were dealt with in practice in the original cultural context.

As we saw in Section 3.3, another point on which Peet and Neugebauer disagreed was the even more fundamental question of the nature of the first group of completions. For Neugebauer, these were preparatory for the calculation of $2 \div 7$ and $2 \div 9$, although he never offered an explanation as to why in that case these problems appear after the $2 \div n$ table in the papyrus. Peet saw them, on the other hand, as useful experimentally-derived relationships that had been noted down by the scribe for possible future use (but not necessarily in the RMP, as there do not appear to be any obvious places where they were used later on). Whether or not Peet was correct on this last point 71 certain minor observations in his edition of the RMP seem to speak against Neugebauer's interpretation of the first group of completions: in Problem 17, for example, Peet saw the implicit use of the previouslyestablished relationship $2 \div 9=\overline{6} \overline{18}$ (Peet, 1923a, p. 57). We do not attempt here to provide any judgement as to whether it was Peet or Neugebauer who was correct in his interpretation; we wish merely to point to their differences in style: Neugebauer as the mathematician, allowing broader mathematical considerations to shape his assessment of the papyrus, versus Peet the Egyptologist, who was much more cautious and more inclined to take the text exactly as it appeared 72

Having made this last remark on Peet's approach to ancient Egyptian mathematics, we bring this paper to a close by returning to the observations

\footnotetext{
${ }^{71}$ We have already noted the view of Gunn and the more up-to-date assessment of Imhausen in footnote 60 above. Chace's view was much like that of Peet (Chace, $1927 / 1929$, vol. I, pp. 23-25), whereas Gillings (1972, pp. 109-119) gives the first group of completions a much more elaborate treatment as the basis for a table of 3 - and 6-term equalities: for example, he derives from Problems 10 and 11, ostensibly by purely ancient Egyptian methods, that $\overline{7} \overline{14} \overline{28}=\overline{4}$.

${ }^{72}$ Although not always strictly so: we saw in footnote 48 how Peet's interpretation of one problem required the assumption of a slip on the part of the scribe. Nor did he always adhere strictly to the ordering of the material in the papyrus: he saw the implicit use of the second group of completions in the calculation of $2 \div 13$ (Peet, 1923a, p. 39). In his review of Peet's edition of the RMP, Gunn suggested that since the scribe was so prone to errors in his writing (see footnote 48 above), he might also have been succeptible to errors in the ordering of the material: Gunn suggested a reordering of the first group of completions which makes the problems more systematic (Gunn, 1926, p. 130).
} 
made at the end of Section 1.3 concerning what Lewis (2016) has termed Peet's 'anti-presentist' stance, which he displayed not only in his wider Egyptological studies, but also more specifically in his several works on ancient Egyptian mathematics. His views on the study of ancient mathematics appear to tally well with modern attitudes within the academic study of the history of mathematics, and yet stand in stark contrast to those of some of the historians of mathematics with whom Peet was contemporary, chief among them being Neugebauer, whose approach is clearly exemplified by the letters that we have presented here: we have seen how the latter let mathematical considerations take the lead in his study, and how he made judgemental reference within the letters to the "rather Egyptian-cumbersome [arithmetical] apparatus". As we have noted (see the quotation at the end of Section 1.3), Peet was more interested in treating ancient Egyptian mathematics on its own terms - even Neugebauer commented upon the "strictly objective manner, ... the avoidance of all artificial hypotheses, and the sure understanding of historical possibilities" that characterised Peet's edition of the RMP ${ }^{73}$ However, perhaps because he wrote mainly for Egyptologists in Egyptological journals, Peet's work in this direction appears to have been largely overlooked by historians of mathematics ${ }^{74}$ These letters offer a glimpse into the nature and significance of Peet's contribution.

\section{Acknowledgements}

We are grateful to Lee, Marcia, and Carol Neugebauer for their permission to publish these letters, as also to the Provost and Fellows of The Queen's College, Oxford, and to the Griffith Institute, Oxford. Thanks must go to T. G. Reid for his help with German transcription, to Dr Philip Ajouri and Prof. Reinhard Siegmund-Schultze for further advice on the German, to Prof. Nathan Sidoli for helpful comments, and also to Clare Lewis for interesting conversations about Peet, and for supplying us with the details of

\footnotetext{
73 "In ihrer streng sachlichen Art, in der Vermeidung aller künstlichen Hypothesen und dem sicheren Verständnis für historische Möglichkeiten ist sie geeignet[,] dem Leser ein vorzüglicher Führer zu sein." (Neugebauer, 1925, p. 70)

${ }^{74}$ There is only one passing reference to him in Dauben and Scriba $(2002$, p. 138) in connection with his edition of the RMP, although a rare nod in his direction may be found in Ritter (2000, p. 133, n. 9), for example. We therefore offer these letters as a glimpse of the nature of Peet's work, and hope to explore it in much greater detail elsewhere.
} 
Neugebauer's membership of the Egypt Exploration Society. We are grateful to Clare Lewis and to Peter M. Neumann for reading a draft of this paper and making useful suggestions, and similarly to the two anonymous referees. We thank Amanda Saville and Tessa Shaw of The Queen's College Library, and also the staff of the Griffith Institute for much help and advice. The first author acknowledges the financial support of the Engineering and Physical Sciences Research Council (UK) via grant number EP/R03169X/1.

\section{References}

Archival sources

Griffith Institute Archive, Oxford: Collection Gardiner MSS (AHG), http://archive.griffith.ox.ac.uk/index.php/alan-hendersongardiner-papers

Griffith Institute Archive, Oxford: Collection Peet MSS, http://archive. griffith.ox.ac.uk/index.php/peet-collection

Shelby White and Leon Levy Archives Center, Institute for Advanced Study, Princeton, NJ, USA: Otto Neugebauer Papers, https://library.ias. edu/sites/library.ias.edu/files/page/MEM . NEUGEBAUER . html

\section{Published sources}

Abdulaziz, A.A., 2008. On the Egyptian method of decomposing $2 / n$ into unit fractions. Hist. Math. 35(1), 1-18.

Adams, C.R., Neugebauer, O., 1955. Obituary: Raymond Clare Archibald. Amer. Math. Monthly 62(10), 743-745; Scripta Math. 21(4) (1956), 293295; also published as: R. C. Archibald and mathematics libraries. Science 123(3198) (1956), 622-623.

Aleksandrov, P.S., 1950. Pavel Samuilovich Uryson. Uspekhi mat. nauk 5(1(35)), 196-202 [in Russian].

Alexandroff, P. [Aleksandrov, P.S.], 1976/1977. Heinz Hopf zum Gedenken. Jahresber. Deutsch. Math.-Verein. 78(3), 113-125; Russian translation: Uspekhi mat. nauk 32(3(195)) (1977), 203-208. 
Aleksandrov, P.S., 1979. Pages from an autobiography. Uspekhi mat. nauk 34(6), 219-249; ibid. 35(3), 241-278 [in Russian]; English translation: Russian Math. Surveys 34(6) (1979), 267-302; ibid. 35(3), 315-358.

Anon, 1962. Otto Neugebauer. Bibliography. Osiris 14, 4-12.

Archibald, R.C., 1933. Obituary: Arnold Buffum Chace. Amer. Math. Monthly 40(3), 139-142+3.

Archibald, R.C., 1938. A semicentennial history of the American Mathematical Society, 1888-1938. American Mathematical Society.

Baines, J., 2013. Egyptologists and the Peet Library of Egyptology and Coptic. The Queen's College Record 8 (9), 60-63.

Bertato, F.M., 2018. A falsa (su-)posição? Tradução dos Problemas 24, 25, 26 e 27 do Papiro Rhind. Rev. Bras. Hist. Mat. 18(36), 11-29.

Bieberbach, L., 1929. Review: 'Die Grundlagen der ägyptischen Bruchrechnung' by Otto Neugebauer. Jahresber. Deutsch. Math.-Verein. 38, 88 kursiv.

Bierbrier, M.L., 2012. Who was who in Egyptology. 4th rev. ed., London: Egypt Exploration Society.

Birch, S., 1868. Geometric papyrus. Z. ägypt. Sprache 6, 108-110.

Bruckheimer, M., Salomon, Y., 1977. Some comments on R. J. Gillings' analysis of the $2 / n$ table in the Rhind Papyrus. Hist. Math. 4, 445-452.

Budge, E.A.W., 1898. Facsimile of the Rhind Mathematical Papyrus in the British Museum. London: British Museum.

Cajori, F., 1927. Review: 'Die Grundlagen der ägyptischen Bruchrechnung' by Otto Neugebauer. Bull. Amer. Math. Soc. 33(3), 371.

Chace, A.B., 1927/1929. The Rhind Mathematical Papyrus, British Museum 100578 and 10058: photographic facsimile, hieroglyphic transcription, transliteration, literal translation, free translation, mathematical commentary and bibliography, 2 vols. Oberlin, Ohio: Mathematical Association of America. 
Dauben, J.W., Scriba, C.J. (Eds.), 2002. Writing the history of mathematics: Its historical development. Basel: Birkhäuser.

Davis, P.J., 1994. Otto Neugebauer: reminiscences and appreciation. Amer. Math. Monthly 101 (2), 129-131.

Egypt Exploration Society, 1919. Report of the thirty-third ordinary general meeting (thirty-seventh annual general meeting), subscription list and balance sheets. London: Egypt Exploration Society.

Egypt Exploration Society, 1943. Report of the fifty-seventh ordinary general meeting (sixty-first annual general meeting), subscription list and balance sheets. London: Egypt Exploration Society.

Eisenlohr, A., 1877/1891. Ein mathematisches Handbuch der alten Aegypter: Papyrus Rhind des British Museum, 2 vols. Leipzig: J. C. Hinrichs.

Erman, A., Grapow, H. (eds.), 1926-1963. Wörterbuch der aegyptischen Sprache. Leipzig: J. C. Hinrichs.

Gardiner, A.H., 1927. Egyptian grammar: Being an introduction to the study of hieroglyphs. Oxford: The Clarendon Press.

Gardiner, A.H., 1934a. Thomas Eric Peet [obituary]. J. Eg. Arch. 20 (1/2), 66-70.

G[ardiner], A.H., 1934b. Thomas Eric Peet [obituary]. The Queen's College Record 2(2), 7.

Gardiner, A.H., Peet, T.E., 1917. The Inscriptions of Sinai. Part I. Introduction and Plates. EEF Memoir, no. 36, London: Egypt Exploration Fund.

Gillings, R.J., 1972. Mathematics in the Time of the Pharaohs. MIT Press.

Gillings, R.J., 1974. The recto of the Rhind Mathematical Papyrus. How did the ancient Egyptian scribe prepare it? Arch. Hist. Exact Sci. 12(4), 291-298.

Gillings, R.J., 1978. Response to: 'Some comments on R. J. Gillings' analysis of the $2 / n$ table in the Rhind Papyrus' (Historia Math. 4 (1977), no. 4 , 445-452) by M. Bruckheimer and Y. Salamon. Hist. Math. 5, 221-227. 
Gillings, R.J., 1979. The Recto of the Rhind Mathematical Papyrus and the Egyptian Mathematical Leather Roll. Hist. Math. 6, 442-447.

Glanville, S.R.K., 1927. The Mathematical Leather Roll in the British Museum. J. Eg. Arch. 13(3/4), 232-239.

Griffith, F.Ll., 1891/1894. The Rhind Mathematical Papyrus. Proc. Soc. Bib. Arch. 13, 328-332; 14, 26-31; 16, 164-173, 201-208, 230-248.

Gunn, B., 1916. Review: 'Von Zahlen und Zahlworten bei den alten Ägyptern, $[s i c]$ und was für andere Völker und Sprachen daraus zu lernen ist. Ein Beitrag zur Geschichte von Rechenkunst und Sprache' by Kurt Sethe. J. Eg. Arch. 3(4), 279-286.

Gunn, B., 1924. Studies in Egyptian syntax. Paris: P. Geuthner.

Gunn, B., 1926. Review: 'The Rhind Mathematical Papyrus: introduction, transcription, translation and commentary' by T. Eric Peet. J. Eg. Arch. $12(1 / 2), 123-137$.

Gunn, B., Peet, T.E., 1929. Four geometrical problems from the Moscow Mathematical Papyrus. J. Eg. Arch. 15(3/4), 167-185.

Gunn, B., Simpson, R.S., 2004. Peet, (Thomas) Eric (1882-1934), Egyptologist, in: Oxford dictionary of national biography, published online: 23rd September 2004 (accessed 5th August 2019).

Helck, W., 1956. Untersuchungen zu Manetho und den ägyptischen Königslisten. Berlin: Akademie-Verlag.

Hughes, S., 1946. Opening bars: Beginning an autobiography. London: Pilot Press Ltd.

Hughes, S., 1951. Second movement: Continuing the autobiography of Spike Hughes. London: Museum Press.

Imhausen, A., 2002. The algorithmic structure of the Egyptian mathematical problem texts. In: Under one sky: Astronomy and mathematics in the Ancient Near East (Steele, J.M., Imhausen, A., Eds.). Alter Orient und Altes Testament, vol. 297. Münster: Ugarit-Verlag, 147-166. 
Imhausen, A., 2003. Ägyptische Algorithmen: Eine Untersuchung zu den mittelägyptischen mathematischen Aufgabentexten. Ägyptologische Abhandlungen, Band 65. Wiesbaden: Harrassowitz Verlag.

Imhausen, A., 2007. Egyptian mathematics, Chapter 1 in: Katz, V. J. (Ed.), The mathematics of Egypt, Mesopotamia, China, India, and Islam: A sourcebook. Princeton: Princeton University Press, 7-56.

Imhausen, A., 2009. Traditions and myths in the historiography of Egyptian mathematics, Chapter 9.1 in: Robson, E., Stedall, J. (Eds.), The Oxford handbook of the history of mathematics. Oxford: Oxford University Press, 781-800.

Imhausen, A., 2016. Mathematics in ancient Egypt: A contextual history. Princeton: Princeton University Press.

Imhausen, A., Ritter, J., 2004. Mathematical fragments: UC 32114B, UC 32118B, UC 32134A+B, UC 32159-UC 32162. In: The UCL Lahun Papyri: Religious, literary, legal, mathematical and medical (Collier, M., Quirke, S., Eds.). BAR International Series 1209, Oxford: BAR.

Irving, R., Maitland, M., 2015. An innovative antiquarian: Alexander Henry Rhind's excavations in Egypt and his collection in the National Museums Scotland. In: Every traveller needs a compass: Travel and collecting in Egypt and the Near East (Cooke, N., Daubney, V., Eds.). Oxford; Philadelphia: Oxbow Books for ASTENE, 87-100.

Jones, A., Proust, C., Steele, J.M. (Eds.), 2016. A mathematician's journeys: Otto Neugebauer and modern transformations of ancient science. Cham: Springer.

Koopman, H.L., Palmer, H.R., Mead, A.D., Archibald, R.C., 1932. Memorial addresses in honor of Arnold Buffum Chace, Alumnae Hall, Pembroke College, April second, 1932. Providence, RI: The Review Club.

Lehto, O., 1998. Mathematics without borders: A history of the International Mathematical Union. New York: Springer.

Lenormant, F., 1867. Note relative à un papyrus égyptien contenant un fragment d'un traité de géométrie appliquée à l'arpentage. C. R. Acad. sci. Paris 65 (25 Nov), 903. 
Lewis, C., 2014. Peet, the JEA and the First World War. Egypt Exploration Society Newsletter (London Edition), no. 11, 8-9.

Lewis, C., 2016. Inaugural lectures in Egyptology: T. E. Peet and his pupil W. B. Emery. Bull. Hist. Arch. 26 (1), article 9, 15pp.

Michel, M., 2014. Les mathématiques de l'Égypte ancienne: numération, métrologie, arithmétique, géométrie et autres problèmes. Connaissance de l'Égypte ancienne 12. Bruxelles: Éditions Safran.

Neugebauer, O., 1925. Review: Peet, T. E., The Rhind Mathematical Papyrus: British Museum 10057 and 10058. Mat. tidsskrift A, 66-70.

Neugebauer, O., 1926. Die Grundlagen der ägyptischen Bruchrechnung. Dissertation, Göttingen [published by Springer the same year].

Neugebauer, O., 1927. Über die Konstruktion von sp "Mal" im mathematischen Papyrus Rhind. Z. ägypt. Sprache 62, 61-62.

Neugebauer, O., 1929. Zur ägyptischen Bruchrechnung. Z. ägypt. Sprache 64, 44-48.

Neugebauer, O., 1930. Arithmetik und Rechentechnik der Ägypter. Quellen und Studien zur Geschichte der Mathematik B 1, 301-380.

Neugebauer, O., 1931. Die Geometrie der ägyptischen mathematischen Texte. Quellen und Studien zur Geschichte der Mathematik B 1, 413-451.

Neugebauer, O. (Ed.), 1935-1937. Mathematische Keilschrift-Texte. 3 vols., Springer, Berlin.

Neugebauer, O. (Ed.), 1955. Astronomical cuneiform texts: Babylonian ephemerides of the Seleucid period for the motion of the sun, the moon, and the planets. 3 vols., London: Lund Humphries for the Institute of Advanced Study, Princeton, NJ.

Neugebauer, O., 1969. Vorlesungen über Geschichte der antiken mathematischen Wissenschaften. 2. unveränderte Aufl. Berlin; New York: SpringerVerlag.

Neugebauer, O., Parker, R.A. (Eds.), 1960-1969. Egyptian astronomical texts. Providence, RI: Brown University Press. 
Neugebauer, O., Sachs, A. (Eds.), 1945. Mathematical cuneiform texts. American Oriental Series, vol. 29, New Haven, CT: American Oriental Society and the American Schools of Oriental Research.

Parkinson, R.B., 2005 [1st ed., 1991]. The tale of the eloquent peasant. Oxford: Griffith Institute.

Parkinson, R.B., 2009. Reading ancient Egyptian poetry: Among other histories. Chichester, Malden, MA: Blackwell-Wiley.

Parkinson, R.B., in press. Libraries in Ancient Egypt, c. 2600-1600 BCE. In: Libraries before Alexandria: The ancient near eastern traditions (Ryholt, K., Barjamovic, G., Eds.), Oxford: Oxford University Press, 113-164.

Peet, T.E., 1920. The Mayer Papyri A \& B, Nos. M1162 and M11186 of the Free Public Museums, Liverpool. London: EES.

Peet, T.E., 1923a. The Rhind Mathematical Papyrus: British Museum 10057 and 10058. London: Hodder \& Stoughton for Liverpool University Press.

Peet, T.E., 1923b. Arithmetic in the Middle Kingdom. J. Eg. Arch. 9(1/2), 91-95.

Peet, T.E., 1930a. Review: 'Die Grundlagen der ägyptischen Arithmetik in ihrem Zusammenhang mit der $2: n$-Tabelle des Papyrus Rhind' by Kurt Vogel. J. Eg. Arch. 16(3/4), 270-271.

Peet, T. Eric 1930b. Review: 'Grundriss der antiken Zeitrechnung' by Wilhelm Kubitschek. J. Eg. Arch. 16(1/2), 165.

Peet, T. Eric 1930c. Review: 'The Rhind Mathematical Papyrus' by A. B. Chace, L. Bull and H. P. Manning. Math. Gaz. 15(210), 266-268.

Peet, T.E., 1931a. A problem in Egyptian geometry. J. Eg. Arch. 17(1/2), 100-106.

Peet, T.E., 1931b. Mathematics in ancient Egypt. Bull. John Rylands Lib. 15 (2), 3-35.

Peet, T.E., 1934a. Review: 'The Decoration of the tomb of Per-Neb: The technique and the color conventions' by Caroline Ransom Williams. J. Eg. Arch. 20(1/2), 119-120. 
Peet, T.E., 1934b. The present position of Egyptological studies: An inaugural lecture delivered before the University of Oxford on 17 January 1934 by the late T. E. Peet, Reader in Egyptology. Oxford: Clarendon Press.

Pingree, D., 1990. Otto Neugebauer 1899-1990. Arch. int. hist. sci. 40, 8284; also published as: Eloge: Otto Neugebauer, 26 May 1899-19 February 1990. Isis 82 (1) (1991), 87-88.

Posener, G., 1951. Sur l'emploi de l'encre rouge dans les manuscrits égyptiens. J. Eg. Arch. 37, 75-80.

Ritter, J., 2000. Egyptian mathematics. In: Mathematics across cultures: the history of non-Western mathematics (Selin, H., Ed.). Dordrecht; London: Kluwer Academic Publishers, 115-136.

Ritter, J., 2016. Otto Neugebauer and ancient Egypt, in: Jones et al. (2016), $127-163$.

Robins, G., Shute, C.C.D., 1987. The Rhind Mathematical Papyrus: an ancient Egyptian text. London: British Museum Publications.

Robson, E., 2007. Mesopotamian mathematics, in: Katz, V. (Ed.), The mathematics of Egypt, Mesopotamia, China, India, and Islam: A sourcebook. Princeton: Princeton University Press, 57-186.

Rowe, D.E., 2012. Otto Neugebauer and Richard Courant: on exporting the Göttingen approach to the history of mathematics. Math. Intelligencer 34(2), 29-37; reprinted as: Otto Neugebauer and the Göttingen approach to the history of mathematics. In: A richer picture of mathematics: The Göttingen tradition and beyond. Cham: Springer, 2018, 357-368.

Rowe, D.E., 2016. Otto Neugebauer's vision for rewriting the history of ancient mathematics. In: Historiography of mathematics in the 19th and 20th centuries (Remmert, V.R., Schneider, M.R., Sørensen, H.K., Eds.). Trends in the History of Science, Basel: Birkhäuser, 123-141.

Sachs, J., Toomer, G.J., 1979. Otto Neugebauer, bibliography, 1925-1979. Centaurus 22 (4), 257-280.

Sarton, G., 1956. Raymond Clare Archibald. Osiris 12, 4-34. 
Sethe, K., 1896. Die Thronwirren unter den Nachfolgern Königs Thutmosis' I., ihr Verlauf und ihre Bedeutung: Die Prinzenliste von Medinet Habu und die Reihenfolge der ersten Könige der zwanzigsten Dynastie. Leipzig: J. C. Hinrichs.

Sethe, K., 1916. Von Zahlen und Zahlworten bei den alten Ägyptern und was für andere Völker und Sprachen daraus zu lernen ist. Ein Beitrag zur Geschichte von Rechenkunst und Sprache. Strassburg: K. J. Trübner.

Siegmund-Schultze, R., 2016. "Not in possession of any Weltanschauung": Otto Neugebauer's flight from Nazi Germany and his search for objectivity in mathematics, in reviewing, and in history, in: Jones et al. (2016), 61106.

Simpson, R.S., 2004a. Gardiner, Sir Alan Henderson (1879-1963), Egyptologist and linguistic scholar, in: Oxford dictionary of national biography, published online: 23rd September 2004 (accessed 5th August 2019).

Simpson, R.S., 2004b. Gunn, Battiscombe George (1883-1950), Egyptologist, in: Oxford dictionary of national biography, published online: 23rd September 2004 (accessed 5th August 2019).

Spalinger, A., 1990. The Rhind Mathematical Papyrus as a historical document. Stud. Altäg. Kult. 17, 295-337.

Swerdlow, N.M., 1993. Otto E. Neugebauer (26 May 1899-19 February 1990). Proc. Amer. Phil. Soc. 137(1), 138-165; shorter version in: J. Hist. Astron. 24(4) (1993), 289-299.

Thompson, J., 2018. Wonderful things: a history of Egyptology, vol. 3. Cairo: The American University in Cairo Press.

Vogel, K., 1929. Die Grundlagen der ägyptischen Arithmetik in ihrem Zusammenhang mit der 2 : $n$-Tabelle des Papyrus Rhind. Universität München.

Wieleitner, H., 1927, Review: 'Die Grundlagen der ägyptischen Bruchrechnung' by Otto Neugebauer. Arch. Geschichte Math. Naturwiss. Tech. 10, 233-237. 